Review

\title{
Use of Biosensors as Alternatives to Current Regulatory Methods for Marine Biotoxins
}

\author{
Natalia Vilariño, Eva S. Fonfría, M. Carmen Louzao and Luis M. Botana * \\ Departamento de Farmacología, Facultad de Veterinaria, Universidad de Santiago de Compostela, \\ Campus Universitario, 27002 Lugo, Spain; E-Mails: natalia.vilarino@usc.es (N.V.); \\ eva.fonfria@usc.es (E.S.F.); mcarmen.louzao@usc.es (M.C.L.) \\ * Author to whom correspondence should be addressed; E-Mail: luis.botana@usc.es; \\ Tel.: +34-982252242; Fax: +34-982252242.
}

Received: 14 September 2009; in revised form: 27 October 2009 / Accepted: 28 October 2009 / Published: 24 November 2009

\begin{abstract}
Marine toxins are currently monitored by means of a bioassay that requires the use of many mice, which poses a technical and ethical problem in many countries. With the exception of domoic acid, there is a legal requirement for the presence of other toxins (yessotoxin, saxitoxin and analogs, okadaic acid and analogs, pectenotoxins and azaspiracids) in seafood to be controlled by bioassay, but other toxins, such as palytoxin, cyclic imines, ciguatera and tetrodotoxin are potentially present in European food and there are no legal requirements or technical approaches available to identify their presence. The need for alternative methods to the bioassay is clearly important, and biosensors have become in recent years a feasible alternative to animal sacrifice. This review will discuss the advantages and disadvantages of using biosensors as alternatives to animal assays for marine toxins, with particular focus on surface plasmon resonance (SPR) technology.
\end{abstract}

Keywords: biosensor; seafood; shellfish poisoning; marine toxins; surface plasmon resonance

\section{Introduction}

Marine biotoxins are compounds with toxic activity that accumulate in fish or shellfish and can cause human illnesses. They are usually produced by phytoplankton and reach shellfish or fish through the trophic chain. Toxic episodes occur as a result of the proliferation of some toxin-producing phytoplankton species or harmful algal blooms. The cause for this proliferation is unknown, in spite of 
an enormous increase in the frequency and worldwide distribution of the toxic bloom reports during the last decades [1], which probably also reflects an international improvement of monitoring programs [2].

The toxicity to humans has been usually reported as acute poisoning, and limits for the content of marine toxins present in seafood destined for human consumption have been set to protect human health. However, the possible chronic toxicity of a repeated exposure to sub-acute doses in humans is completely unknown for all the toxins. The impact of these toxic episodes reaches also ecological and economic levels. Marine wild animals that feed on contaminated species, such as marine mammals and birds, may present signs of intoxication and even die. The presence of a toxic bloom also generates important economic losses to the aquaculture sector and fish industry, as a consequence of the official regulations regarding toxin content in seafood and the bad publicity generated by human poisoning outbreaks $[3,4]$.

Although marine toxins were initially classified according to the acute poisoning syndrome they induce in humans, nowadays a classification based on their chemical structure seems to be more widely accepted. In this review we will focus on the following groups of marine toxins: okadaic acid and derivatives, yessotoxins, pectenotoxins, azaspiracids, brevetoxins, cyclic imines, saxitoxin and derivatives, domoic acid, ciguatoxins and palytoxin and derivatives.

The implementation of appropriate regulatory limits for toxin contents in seafood destined to human consumption requires the availability of suitable detection methods, sensitive and reliable enough, to detect the presence of the toxins at the stated levels. Until very recently the regulations of most countries based the detection of marine toxins mainly on laboratory animal bioassays, except for the detection of domoic acid, which regulatory detection was by liquid chromatography high performance liquid chromatography with ultraviolet detection (HPLC-UVD) [2]. Therefore the detection of the regulated toxins, okadaic acid and derivatives, pectenotoxins, yessotoxins, saxitoxin and derivatives, and azaspiracids, has been done for decades by administration of the toxin to animals, in spite of the well known drawbacks of these techniques. Besides the ethical issues arising from the prolonged suffering and sacrifice of laboratory animals, these bioassays have also technical deficiencies, such as lack of sensitivity (the detection limits are often close to the regulatory limits), lack of specificity (the toxins cannot be identified and individually quantified), duration of the assay (too lengthy for the lipophilic toxins) and too high a rate of false positives and negatives [5-7].

Although the desire to move away from animal bioassays has been recognized in the legislation of many countries, such as in the European Directive 86/609/EEC [8], for a variety of alternative detection methods that have been developed during the last decades the criteria for substitution set by regulatory authorities are difficult to meet. These rigid criteria are aimed to guarantee consumer protection and, unless there is solid evidence of an adequate level of protection by internationally validated methods, regulatory authorities are reluctant to accept replacements. Currently, the detection of saxitoxin and analogs by high performance liquid chromatography with fluorimetric detection (HPLC-FLD) is officially accepted in some countries [9,10] and an ELISA (enzyme-linked immunosorbent assay) has also been published as an AOAC method for the detection of domoic acid [11].

In addition to the officially accepted methods, there is a wide variety of techniques that have been developed for the detection of marine toxins. Among them there are several analytical methods such as 
high performance liquid chromatography (HPLC) with UV or fluorimetric detection, liquid chromatography-mass spectrometry (LC-MS), and liquid chromatography-tandem mass spectrometry (LC-MS/MS), that have been optimized for many toxin groups and have become very popular in recent years. These analytical methods allow the unequivocal identification of the toxins present in a sample and their quantification with high levels of sensitivity. However, they require specialized laboratory personnel and expensive equipment. A major disadvantage of these methods is the need of certified standards for each known analogue of every group of toxins in order to evaluate total toxicity, and in any case the contribution of unknown compounds to sample toxicity will not be considered. The lack of standards is an important obstacle for the substitution of the mouse bioassay by other analytical methods. Another group of alternative techniques are biological methods that have also been developed for most of the toxin groups with a great variety of designs, from cytotoxicity assays to biosensor techniques. These methods vary in specificity, but none of them can identify the different analogues of a toxin group. Their practicality depends on the technological approach, as well as their cost. Biosensor technologies can offer cost-effective solutions for marine toxin detection with suitable characteristics of group specificity, sensitivity, portability, repeatability and robustness. One of the problems of the present situation regarding the analysis of marine toxins is the lack of uniformity in the analytical outcomes by different laboratories. The characteristics of biosensors would support their use, not only to obtain more uniform results, but also to comply with the rapidly increasing demands of certification and traceability of traded seafood.

Biosensor-based technologies have been widely used in the last 15 years for pharmacological, environmental and food safety applications [12-14]. A biosensor is an analytical device incorporating a biorecognition element intimately associated with or integrated within a transducer that converts the biological response into an electrical signal. A great variety of detection techniques can be included in this definition. The biological response could be anything from enzyme activity or antibody/receptor binding to cell responses. The transduction to an electrical signal could also be diverse. Biosensor technologies include transduction platforms based on electrochemical (potentiometric, amperometric, impedance), piezoelectric, thermal or optical methods (reflectrometric interference spectroscopy, interferometry, optical waveguide lightmode spectroscopy, total internal reflection fluorescence, surface plasmon resonance...) [14,15]. These techniques have been adapted to detect analytes of interest based on the interaction with or functionality modification of a biological target, which could be nucleic acids, enzymes, antibodies, receptors, cell organelles or whole cells [12-16]. The specificity of the detection is determined by the biological component of the method. For example, a method based on binding to a specific antibody would be very specific, however whole cell-based biosensors usually lack that degree of specificity and that characteristic could be used as an advantage in a broad-spectrum detection/monitoring technique. The sensitivity, on the other hand, as well as the portability of the device, depends on the signal transducer. In recent years the microfabrication tools have made possible the idea of microbiosensors or nanobiosensors, a very young branch of biosensors with a technologically challenging future [13]. However the statistical significance of single molecule/cell detection should be addressed before extended use of these techniques. Biosensor assays may have mainly two designs, a direct or an indirect format [13]. The direct format is based on the detection of analyte binding to a target or being cleaved by an enzyme, for example. In the indirect format an additional reaction has to occur in order to detect the analyte, for example the analyte may 
inhibit the interaction of the biological target with a "reporting element". Indirect assays are often used in food analysis because they usually display lower interferences with complex matrixes. Actually, sample preparation is commonly a critical step in method development when working with food samples due to their complexity, and seafood is not an exception. Therefore, attention should be paid not only to the efficiency and sensitivity of the biosensor assay but also to the sample preparation procedure. This review will revise the biosensor techniques that have been developed for the detection of the different groups of marine biotoxins. Although the main focus will be on biosensor devices, other techniques that use biological responses for toxin detection will be also included, since their scientific approaches and technical developments may serve as basis for future biosensor designs in seafood toxin detection.

\section{Okadaic Acid and Derivatives}

Okadaic acid (Figure 1) and its derivatives are the causative agents of the so-called diarrheic shellfish poisoning (DSP). These toxins have a worldwide distribution with a higher occurrence in Europe and Japan [17]. The group includes okadaic acid and dinophysistoxins, which are produced by microalgae of the genus Dinophysis and Prorocentrum [18-20]. These compounds are well known inhibitors of protein phosphatases, mainly PP2A and PP1 [21,22]. DSP is produced by acute intoxication after consumption of contaminated mollusks and includes gastrointestinal symptoms, such as nausea, vomiting and diarrhea, and headaches [23]. Although no fatalities have been reported, these toxic episodes cause high economic losses, both in the health care and aquaculture sectors. The presence of DSP toxins in shellfish destined for human consumption is legislated in many countries. In most countries the regulatory limit for okadaic acid and derivatives and pectenotoxin, based on the acute intoxication data, is $0.16 \mathrm{mg}$ of okadaic acid equivalents per $\mathrm{kg}$ of shellfish meat (whole body or any edible part) and the official detection method is the mouse bioassay [2,24]. The European regulation contemplates alternative detection methods for lipophilic toxins including HPLC with fluorescence detection, liquid chromatography-mass spectrometry, immunoassays and functional assays such as the phosphatase inhibition assay [25], however the lack of validation studies and standards for all the required analogues of each group have precluded their implementation as alternatives to the mouse bioassay in the EU. The chronic toxicity of these toxins to humans is unknown, but the tumour promoting effects observed in animals [26,27] have raised concerns about the current safety limits both in the scientific and health care communities.

Several immunosensors have been developed for the detection of okadaic acid and its derivatives. Different transduction technologies were adapted for the immunodetection of okadaic acid, including quartz crystal microbalance [28], chemiluminiscence integrated into a flow injection analysis system [29], surface plasmon resonance [30,31] and electrochemical methods [32-34]. All these DSP-immunobiosensors are designed as competition assays with enough sensitivity to detect okadaic acid at the concentrations required by the current legislation. However, the recently published, enzymatic recycling system for signal amplification coupled to an amperometric immunosensor displays a substantial improvement in sensitivity [32]. The problem of most immunosensors is the lack of correlation between the cross-reactivity of the antibody with each toxin analog and the toxic potency 
in vivo. This problem has been overcome for okadaic acid, dinophysistoxin-1 and dinophysistoxin-2 with the development of a monoclonal antibody used in a SPR-based biosensor, which cross-reactivity towards these three compounds matches their toxic potency both in buffer and shellfish extract [31].

Figure 1. Chemical structures of lipophilic toxins.

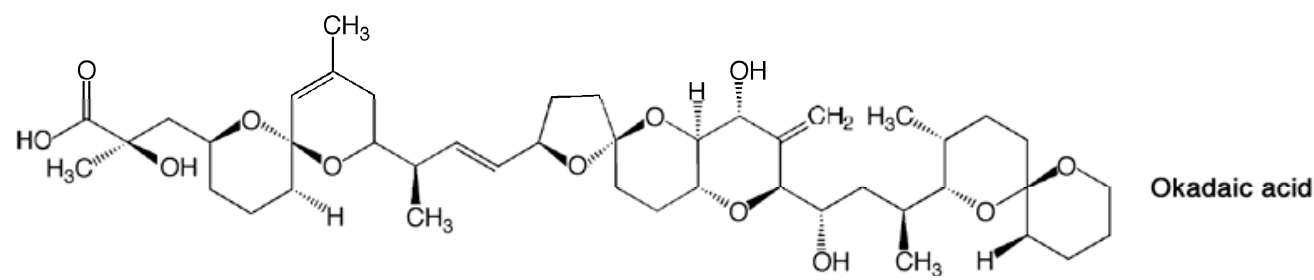

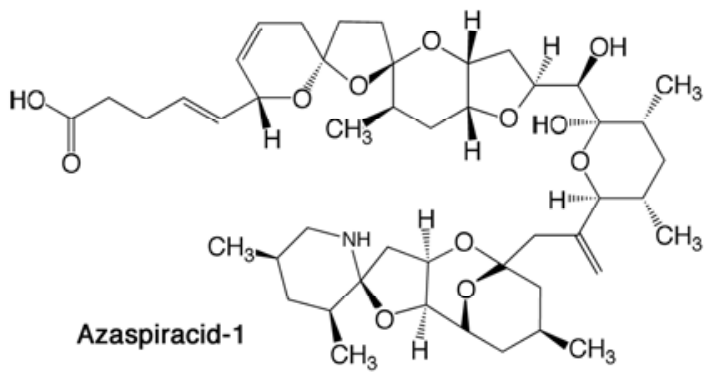

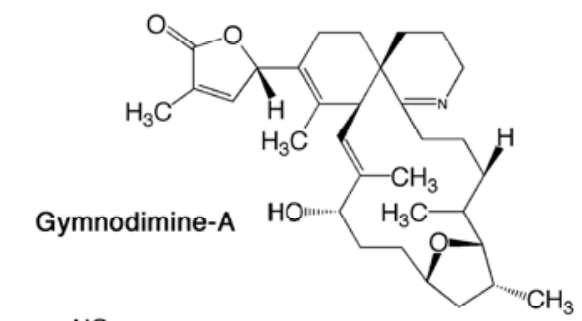

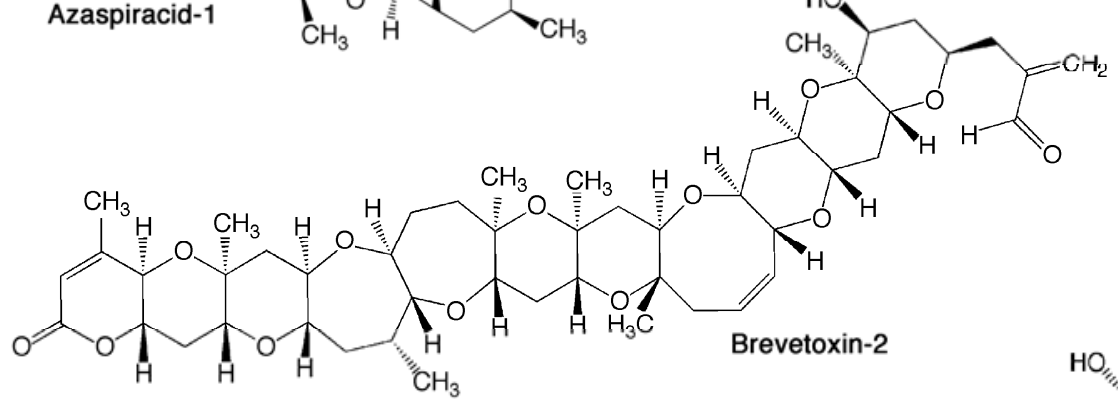

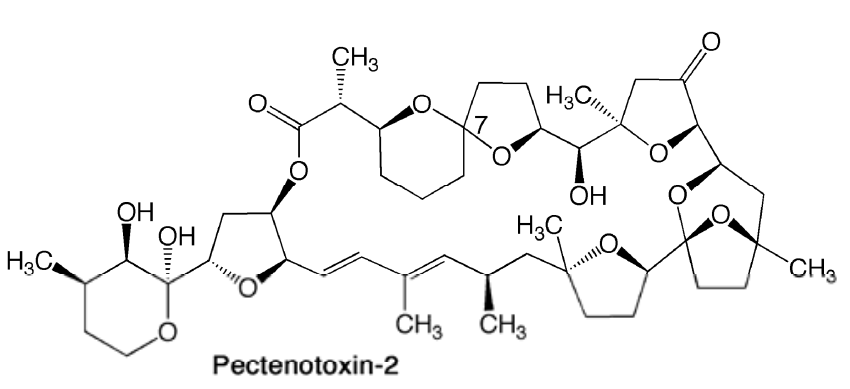

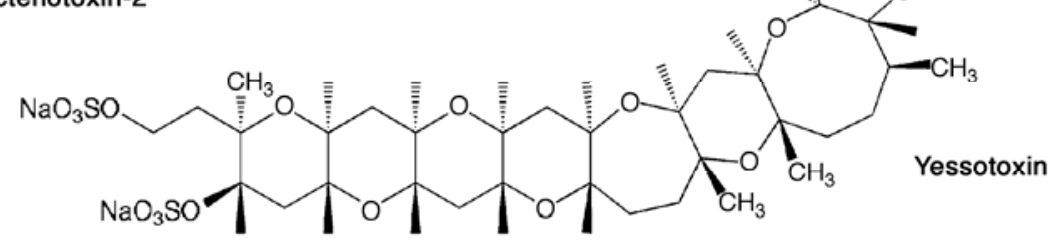

DSP toxin biosensors have also been developed using a well known target of these group of toxins, the protein phosphatase PP2A $[35,36]$. The inhibition of the enzymatic activity of PP2A is measured by electrochemical detection, either by direct immobilization of the enzyme on a screen-printed electrode [35] or using a bienzyme amplification system with off-line enzymatic incubation with PP2A [36]. Although the second approach offers a higher sensitivity, the first enzyme biosensor has also enough sensitivity to detect okadaic acid contents below the limit established by the legislation, however their performance with shellfish matrixes has not been tested yet. 
Intense work in the development of ELISAs [32,37] and phosphatase inhibition assays [38-41], for the detection of DSP toxins, has been the basis for the wide array of biosensor technologies designed for the detection of these compounds. Some detection methods based on the in vitro cytotoxicity of DSP toxins have been also described [42-44], and although they have several drawbacks, such as practicality of use and lack of specificity for the identification of toxins, they might be the basis for future developments of universal cell-based detectors for marine toxins. The analytical methods that can be used to detect these toxins include LC-MS and HPLC-FLD [45-49].

\section{Pectenotoxins}

Pectenotoxins are macrocyclic polytethers (Figure 1) that accumulate in filter-feeding shellfish. They are produced by microalgae of the genus Dinophysis and pectenotoxin-contaminated shellfish has been reported from countries all over the world [50]. About 13 pectenotoxins have been described as natural compounds present in shellfish, with structural variations that determine important variations in toxicity [51]. The parental phytoplanktonic compounds display a higher toxicity that is reduced after transformation by shellfish. Although these toxins were initially classified in the DSP group, their diarrheic toxicity to humans has not been proven. Actually, it has been recently demonstrated that oral administration to mice does not cause any toxic effect, in spite of the toxicity induced by intraperitoneal administration [52,53]. The mechanism of action of pectenotoxin seems related to the disruption of the actin cytoskeleton observed in vitro [54-57]. The presence of pectenotoxins in seafood is regulated in several countries. In the EU, as well as in New Zealand and Chile [2], the content of okadaic acid, dinophysistoxins and pectenotoxins must not exceed $0.16 \mathrm{mg}$ of okadaic acid equivalents/kg of shellfish meat [24].

Besides the mouse bioassay there are not many methods available for the detection of pectenotoxins that use biological components. To our knowledge no anti-pectenotoxin antibodies have been reported so far, probably due to the small amount of pure pectenotoxins available worldwide. Functional, multitoxin detection assays have been developed based on the induction in hepatocytes of apoptosis or cytotoxicity by several toxins, including pectonotoxins [58], but this cell based-assay is not specific for pectenotoxins and although its performance with shellfish extracts was tested, it is not very practical since apoptosis is judged by microscopy. Another multitoxin detection assay based on cytotoxicity in differenct cell models has been described recently that includes the detection of pectenotoxin with a more practical approach [42]. However, as we said above the field of cell-based biosensors is growing fast and their use as universal toxin detectors may hold interesting options for marine toxin detection in the future. These toxins can also be detected by the chemical detection methods HPLC-UVD, HPLC-FLD and LC-MS [18,47-49,59,60].

\section{Yessotoxins}

Yessotoxins are a group of marine toxins with a ladder shape polycyclic ether structure (Figure 1). There are more than 36 compounds in this group of toxins [61]. Like other groups of marine toxins, yessotoxins have phytoplanktonic origin (Protoceratium reticulatum, Lingulodinium polyedrum, 
Gonyaulax spinifera) [62-64] and a worldwide distribution [61,65]. Although yessotoxins were initially included in the DSP toxin group, no diarrheic effects have been reported in humans and they have been demonstrated to have no diarrheic effects in mice by oral administration [66,67]. However they display a high intraperitoneal toxicity in the mouse bioassay $[66,68]$. Their mechanism of action is still unclear. Several in vitro cellular effects have been reported, but their correlation to in vivo toxicity of yessotoxin, which is considered a cardiotoxic compound, remains to be elucidated. The presence of yessotoxins in shellfish is regulated in Europe and other countries [2]. The regulatory limit is $1 \mathrm{mg}$ of yessotoxin equivalents per $\mathrm{Kg}$ of shellfish meat (whole body or any edible part) [24].

Several biosensor-based techniques have been developed for the detection of yessotoxin. Surface plasmon resonance and resonant mirror biosensors have been used for its detection based on its interaction with phosphodiesterase enzymes, using either direct format or competition format assays [69-72]. The interaction with phosphodiesterase allows the detection of yessotoxin in the low $\mu \mathrm{M}$ range, enough for current regulatory limits, however the method is not as specific as immuno-based biosensors, since other compounds such as the brevetoxin $\mathrm{PbTx} 1$ and other polyethers can also interact with phosphodiesterases [72]. Other methods with biological components include a microplate assay based on the activation of phosphodiesterase enzymatic activity by yessotoxins [73], which was the basis for the development of these biosensor methods, and a direct assay that detects the interaction of these toxins with phosphodiesterases by fluorescence polarization [74]. Another functional method for the detection of yessotoxin involves measurement of the E-cadherin fragment ECRA100 and total E-cadherin by protein blot [75,76]. Although sample processing was shortened recently, this technique takes much longer than the previously mentioned methods, since a $20 \mathrm{~h}$ incubation of the cells in the presence of toxin is required. Additionally, this method is not specific for yessotoxins because the same fragment of E-cadherin can be detected after azaspiracid treatment, and both toxins have similar potency and efficacy [77]. ELISAs are also available for the detection of yessotoxins [78,79]. ELISAs are fast, sensitive and specific and can be used as screening assays for high numbers of samples. However, the cross-reactivity of the antibodies with the different yessotoxins does not match their relative toxic potencies, and the antibodies used in these assays are polyclonal and therefore their stock is limited. Additionally, there is an overestimation of toxin content versus LC-MS, which could be expected given the fact that quantification by LC-MS was done only for three toxins of this group, but no comparison to mouse bioassay results was done. As mentioned a few lines above, the detection of yessotoxin is also possible by LC-MS, besides the other analytical methods HPLC-FLD and capillary electrophoresis [47-49,80-82].

\section{Azaspiracids}

The azaspiracids were described for the first time in 1995 [83]. This group of toxins comprises more than 20 analogs (the azaspiracid-1 structure is given in Figure 1) [84-88]. They are produced by phytoplankton (Protoperidinium crassipes) and accumulate in shellfish through the trophic chain [89]. Some compounds have been isolated only from shellfish and they are thought to be the product of metabolization of the parent phytoplanktonic compounds. The presence of these toxins has been described in shellfish from Ireland, United Kingdom, Spain, France, Norway and Morocco [83,90-93], 
among others. Human intoxication by azaspiracid-contaminated shellfish (azaspiracid poisoning, AZP) has been reported and includes nausea, diarrhea and headache symptoms, similar to DSP. The content of azaspiracids in shellfish destined to human consumption is regulated in many countries; in the EU the regulatory limit is $160 \mu \mathrm{g}$ of azaspiracid equivalents $/ \mathrm{kg}$ of shellfish meat (whole body or any edible part) [24]. The European official method for the detection of azaspiracids is the mouse bioassay [25].

Currently, there is no biosensor assay for the detection of azaspiracids, and besides the mouse bioassay, there are only two other options for the detection of these toxins. LC-MS techniques have been optimized for the detection of azaspiracids [48,49], although quantification and identification is possible only for those compounds that have available certified standards. Azaspiracid-specific antibodies have been produced recently, and shown to bind several azaspiracid analogs (Aza-1, 2, 3 and 6) $[94,95]$. Competition and sandwich ELISAs were designed with these antibodies and a synthetic fragment of the azaspiracid molecule that is conserved for many analogs. Hopefully, in the near future these new antibodies will be available for the detection of azaspiracids in electrochemical or optical immunosensors.

\section{Brevetoxins}

Brevetoxins (PbTx, Figure 1) are lipophilic polyether toxins responsible for neurotoxic shellfish poisoning (NSP). They are classified into two types, depending on their backbone structure: type A (PbTx-1, 7, 10) and type B (PbTx-2, 3, 5, 6, 8, 9, 11, 12, 13, 14) [96]. Globally, they occur mainly in Mexico, USA and New Zealand and they are produced by the species Karenia brevis [97,98]. Brevetoxins bind with high affinity $\left(K_{D} 1-50 \mathrm{nM}\right)$ to site 5 of the voltage-dependent sodium channel $\alpha$-subunit [99] resulting in a sustained sodium influx and consequent depolarisation of neural membranes. This property causes their toxic effects in humans, which include gastrointestinal and neurologic symptoms such as nausea, vomiting, diarrhoea, chills, hot-cold flashes, hypotension, cramps, arrhytmias, paraesthesia, motor incoordination, double vision, bronchoconstriction and paralysis $[65,100]$. Although brevetoxins have been related to the death of fish, birds and some marine mammals [101-103], no human mortalities associated with these toxins have been reported to date. Currently, the accepted detection method for brevetoxins is the mouse bioassay with diethyl ether extraction of shellfish tissue based on the American Public Health Association (APHA) method [104]. Basically, any detectable level of brevetoxins per $100 \mathrm{~g}$ of shellfish tissue was considered potentially unsafe for human consumption. In practice, a residue toxicity $\geq 20 \mathrm{MU}$ (mouse unit: amount of crude toxic residue that will kill 50 percent of the test animals in 930 minutes [105]) per $100 \mathrm{~g}$ shellfish tissue was adopted as the guidance level for closure of shellfish harvesting areas in USA, Mexico and New Zealand $[2,65]$.

Apart from mamamalian bioassays, several methods have been developed to detect brevetoxins. In the biosensors field, a surface plasmon resonance-based detection method for ladder-shaped polyeher compounds (among them brevetoxin-2) has been recently published [72]. The ability of these molecules to inhibit the interaction of desulfo-yessotoxin to phosphodiesterase II was used to design an indirect assay format that can detect several toxins. In the case of PbTx-2, inhibition was achieved in the $\mu \mathrm{M}$ range. However, this assay has not been tested in shellfish matrixes and the data point to a lack 
of specificity since toxins from different groups can be detected, including yessotoxins. Besides this SPR technique, there is an immunosensor with amperometric detection [33] that allows the detection of PbTx-3 in the $\mathrm{ng} / \mathrm{mL}$ range. Finally, a neuronal network biosensor has been also developed for the detection of the neurotoxins PbTx-3 and saxitoxin in buffer and diluted seawater [106]. The main feature of this method is its high sensitivity with detection limits of $296 \mathrm{pg} / \mathrm{mL}$ and $12 \mathrm{pg} / \mathrm{mL}$ for $\mathrm{PbTx}-3$ and saxitoxin, respectively, although it lacks specificity.

Other detection methods that use biological components for the detection of brevetoxins include receptor binding assays [107], radioimmunoassay [108,109], ELISA [79,110,111] and fluorimetric assays based on changes in membrane potential [112]. The analytical methods that have been used to detect this group of toxins are LC-MS [113] and micellar electrokinetic capillary chromatography (MEKC) coupled to laser-induced fluorescence detection [114].

\section{Cyclic Imines}

The cyclic imines phycotoxins are a heterogenous emerging group of marine compounds that includes the gymnodimines (Figure 1), spirolides, pinnatoxins, pteriatoxins, prorocentrolides and spiroprorocentrimines [115]. All of them share an imine group as a part of a cyclic ring system within their molecular framework. They are produced by microalgae of species that differ among the cyclic imine subgroups. Although their mechanism of action is not fully understood, it has been demonstrated that gymnodimines and spirolides target the nicotinic acetylcholine receptors [116-118]. The cyclic imines display a "fast acting toxicity" with an acute threshold response ("all or nothing") in mammalian bioassays [119]. At lethal concentrations they cause death in a few minutes after intraperitoneal injection, while at sublethal doses mice recover rapidly. Their toxic potential is much lower via the oral route [120]. At present, no human intoxication has been unequivocally linked to these toxins and they are not still regulated, although they may pose a real threat to human health. Moreover, due to their high toxicity by intraperitoneal administration, the cyclic imines are a source of false positives in DSP and NSP toxin detection by the mouse bioassay. Several detection methods for these toxins have been developed while the scientific community works to provide more toxicological data for a more informed evaluation of the human health threat related to these toxins.

Until recently, the cyclic imines could only be detected by mouse bioassay and LC-MS-based detection techniques [48,121-125]. The only method currently available that has a biological component, besides the mouse bioassay, is a fluorescence polarization assay for the detection of gymnodimines and spirolides [126]. A competition assay format uses the ability of these compounds to inhibit the interaction between nicotinic acetylcholine receptors and $\alpha$-bungarotoxin. This method allows the quantification of gymnodimine-A and 13-desmethyl $\mathrm{C}$ spirolide in the $\mathrm{nM}$ range. This assay is sensitive enough to detect concentrations of these toxins higher than $85 \mu \mathrm{g} / \mathrm{kg}$ in shellfish meat using an acetone/chloroform extraction with acceptable recovery rates. The use of a biological target and its well known specific interaction with $\alpha$-bungarotoxin, avoids the interference of other phycotoxins, ensuring its specificity [126]. 
Figure 2. Chemical structures of hydrophilic toxins.

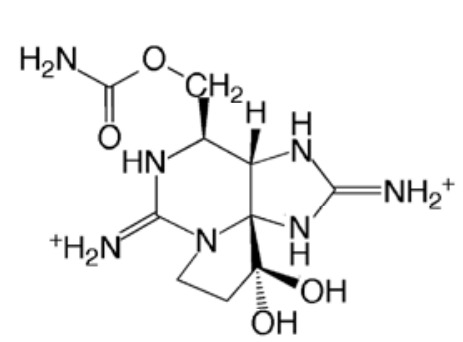

Saxitoxin

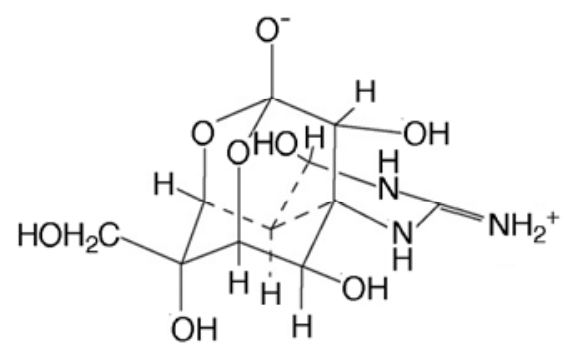

Tetrodotoxin<smiles>C/C(=C/C=C/[C@@H](C)C(=O)O)[C@H]1CN[C@H](C(=O)O)[C@H]1CC(=O)O</smiles>

Domoic acid

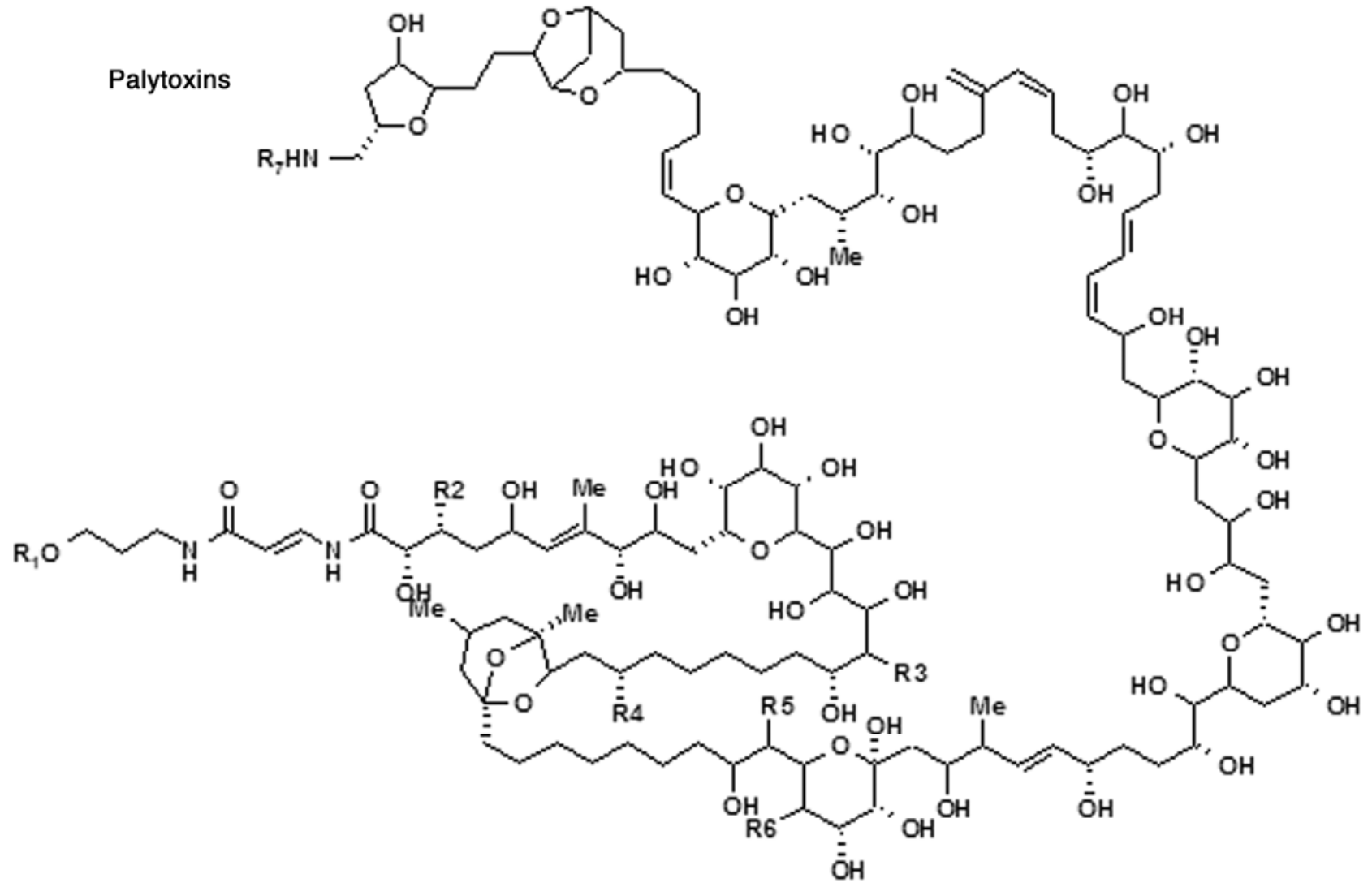

\section{Saxitoxin and Analogues}

This phycotoxin group comprises saxitoxin (STX, Figure 2) and its analogues, more than 24 potent water-soluble neurotoxins that differ in combinations of hydroxyl and sulphate substitutions located at four sites of a tetrahydropurine backbone. Based on substitutions at $\mathrm{R}_{4}$, the saxitoxins can be subdivided into four groups: the carbamate, sufocarbamoyl, decarbamoyl and deoxydecarbamoyl toxins [99]. These toxins are responsible for paralytic shellfish poisoning (PSP), the most widespread algal-derived shellfish poisoning worldwide. On a global basis, almost 2,000 cases of human intoxications are reported per year, with a $15 \%$ mortality rate [127]. STX and analogues are produced by the genus Alexandrium, Gymnodinium and Pyrodinium and elicit their effects by binding with high affinity to site 1 of the voltage-dependent sodium channel $\alpha$-subunit $[128,129]$ and blocking the sodium influx that prevents the generation and propagation of action potentials in excitable 
cells $[130,131]$. This molecular effect causes both neuronal and gastrointestinal symptoms in humans; such as numbness, headache, dizziness, nausea, vomiting, diarrhea, parestesia, paralysis, hypotension, respiratory difficulty and in extreme cases death [132]. Currently, in the European Union and in most of American and Asiatic countries a regulatory limit of $800 \mu \mathrm{g}$ of saxitoxin equivalents $/ \mathrm{kg}$ of any edible part of molluscs has been established [2,24], being the mouse bioassay the official method for their detection [25]. Recently, a new detection method has been validated in North American and European countries, a high performance liquid chromatography method with fluorescence detection (HPLC-FLD), the so-called Lawrence method [10,133].

Several biosensor techniques have been adapted to the detection of PSP toxins. Chemosensors based on the photoinduced electron transfer (PET) principle sense toxins by means of synthetic fluorophores, since the toxin binding produces a fluorescence enhancement. Coumaryl [134], anthracylmethyl [135], acridinylmethyl [136] and boron azadipyrrin [137] crown ethers have been synthesised and evaluated as fluorescence recognition molecules for STX. Among them, boron azadipyrrin crowns, with a binding constant for STX in the $\mu \mathrm{M}$ range, allowed working in the visible region of spectrum, far from any shellfish matrix absorption bands. The detection limit of the mouse bioassay used for PSP toxins determination corresponds approximately to $1 \mu \mathrm{M}$ of STX, and the detection limit of this chemosensor assay is slightly below it [137]. New fluorophores are being investigated to improve its performance. A surface plasmon resonance-based assay for the detection of saxitoxin and analogues has also been recently published [138,139]. An inhibition format was designed using a STX-chip and monoclonal or polyclonal antibodies. This method allows the quantification of several STX analogues (STX, dcSTX, C1/2, GTX2/3, dcGTX2/3 and GTX5) at concentrations five times lower than the regulatory limit in extracts of several shellfish matrixes. In spite of the low cross-reactivity of the antibodies with toxins hydroxylated at the site $\mathrm{R} 1$, which is a common feature of the antibodies developed against PSP toxins [140,141], its performance with natural shellfish samples (in relation to mouse bioassay and HPLC-FLD method) supports its use as a screening method for saxitoxin and analogues detection. Besides this two methods, some other biosensor assays based on functional responses that can detect PSP toxins are being discussed in the tetrodotoxin section, since they where initially developed for this other toxin that has the same mechanism of action as PSP toxins. Also, the neuronal network biosensor described in the brevetoxin section has been reported to detect saxitoxin with high sensitivity [106].

In addition to these techniques, saxitoxins and analogues can be detected by radioimmunoassay [141], receptor binding assays [142-144], electrophysiological assays [145], fluorimetric assays based on changes in membrane potential [146,147] and ELISA [79,140], all of them based on biological detection and the analytical technique capillary electrophoresis [148], among others.

\section{Domoic Acid Group}

This phycotoxin group comprises ten potent water-soluble neurotoxins, domoic acid (DA, Figure 2) and its isomers, which are responsible for amnesic shellfish poisoning (ASP) [149]. This group of toxins produced by the genus Pseudonitzschia and Nitzschia and Chondria armata has a worldwide distribution [150-153]. The mechanism of action of these compounds involves their 
interaction with kainate receptors $\left(\mathrm{K}_{\mathrm{D}} 5 \mathrm{nM}\right.$ [99]), a subclass of glutamate receptors, and their activation. ASP symptoms in humans include nausea, vomiting, diarrhea, abdominal cramps, dizziness, headaches, disorientation, memory loss, seizures, coma and death in extreme cases [154]. In the European Union, the regulatory limit for the total ASP toxin content in the edible parts of molluscs is $20 \mathrm{mg} / \mathrm{kg}$ [24], being the reference method to detect these toxins the HPLC-UVD [25]. The mouse bioassay is not useful to detect domoic acid in shellfish since the detection limit of this technique for ASP toxins $(400 \mathrm{mg} / \mathrm{kg})$ is higher than the regulatory limit. Recently, an ELISA has been published as AOAC Method for the detection of DA in shellfish and approved as official detection method in many countries $[11,155]$.

Several immunosensors have been designed for the detection of domoic acid with different transducer technologies. For surface plasmon resonance technology, the toxin was covalently linked to a gold-coated chip with mixed oligo ethylene glycol self-assembled monolayers [156], and subsequently the DA in solution was detected by competition with the immobilized toxin for binding to an anti-DA monoclonal antibody. The detection limit was $0.1 \mathrm{ng} / \mathrm{mL} \mathrm{DA}$, showing better results than the ELISA performed using the same antibody [157]. A second SPR-based assay for the detection of DA was developed using a chip with DA immobilized on its surface and a rabbit polyclonal antibody. A simple extraction with methanol allows the detection of DA in the range of $\mathrm{ng} / \mathrm{g}$, in scallops, cockles, mussels and oysters [158]. Also using a surface plasmon resonance-based transducer, another DA detection method combines recognition elements based on ultra-thin molecularly imprinted polymer (MIP) films [159]. Although its sensitivity is still low, these synthetic receptors are promising since their stability and performance in SPR instruments are better than for natural targets. Two electrochemical-based immunosensors have been developed using screen-printed carbon electrodes coupled to amperometric [33] or differential pulse voltametry detection [160]. In both cases, the presence of DA is detected by competition with immobilized DA for binding to an anti-DA antibody and the signal is generated by an electroactive product of alkaline phosphatase. The detection limits of these techniques are similar: $2 \mathrm{ng} / \mathrm{mL}$ and $5 \mathrm{ng} / \mathrm{mL}$, respectively, but differ in the analysis time (30 min and $150 \mathrm{~min}$ respectively). Both methods would allow the on-site measurement of DA. These techiques are useful for the detection in mussel matrix with good performance and good recovery rates (higher than $83 \%$ ). Domoic acid can also be detected by LC-MS [47,161], thin-layer chromatography (TLC) [162] and capillary electrophoresis (CE) [163].

\section{Ciguatoxins}

Ciguatoxins (CTXs) are a family of lipid-soluble highly oxygenated cyclic polyether compounds which act by binding to site 5 of the voltage-dependent sodium channel $\alpha$-subunit, a site overlapping the brevetoxin binding site $[65,164,165]$. These toxins are the main agents responsible for ciguatera fish poisoning (CFP), a seafood intoxication caused by ingestion of some species of tropical and subtropical reef fish. CFP presents neurological (paresthesia, dizziness, headache, numbness, ataxia, coma and death), gastrointestinal (diarrhea, nausea, vomiting and abdominal pain) and cardiac symptoms (bradycardia and hypotension) [99]. Although it is rarely fatal, CFP affects more than 50,000 people annually [99]. Very few specific regulations exist for ciguatera toxins [166]. In the 
European Union, Regulation (EC) No 853/2004 establishes that fishery products containing biotoxins such as ciguatoxins must not be marketed but no information about analytical methods is given [24]. Traditionally, the mouse bioassay based on the method described by Banner et al. has been used to detect CTXs in contaminated fish [65] but its lack of specificity and other associated problems encouraged the development of alternative methods.

No biosensor-based method is available for the detection of CTXs. A recent publication of a surface plasmon resonance-based detection method for ladder-shaped polyether compounds similar to CTXs [72] may offer a possibility for the detection of this class of toxins by biosensors, although CTX was not tested in this assay and the sensitivity of the method for the other toxins suggests a difficulty to comply with the low CTX detection limits required to ensure human safety.

Other methods that use biological components have been developed for the detection of CTXs, such as RIA [167], ELISA [168-171], rapid enzyme immunoassay stick test [172,173] or fluorimetric assays based on changes in membrane potential [112]. CTXs can also be detected by LC-MS [174].

\section{Palytoxins and Ostreocins}

Palytoxin (Figure 2) is a more complex and one of the more potent marine biotoxins [175]. Palytoxin and its analogs were initially found in marine zoanthid corals and sponges and also in some species of dinoflagellates, such as Ostreopsis siamensis and Ostreopsis ovata, but it has been also described in fish and shellfish [176]. The hypothesis of a symbiotic bacterial origin for this group of toxins has been explored in some recent works [177,178]. Although the palytoxin-containing zoanthid organisms are located in tropical waters, the dinoflagellates of the genus Ostreopsis have a worldwide distribution and toxin producing species have been described not only in tropical and subtropical waters, but also in the Mediterranean Sea [179-182]. Humans show symptoms of intoxication by palytoxin following ingestion of contaminated seafood or exposure to seawater aerosol in bathing areas. Oral poisoning can induce among other symptom vomiting, diarrhea, paresthesia of the extremities, myalgia, repiratory distress and death [183-185], while exposure to the toxin by aerosol induces rhinorrhea, cough, fever and broncoconstriction [186]. The mecanism of action of this toxin, at least for its in vitro effect on cells, involves binding to the $\mathrm{Na}^{+} / \mathrm{K}^{+}$ATPase and converting the functionality of the pumps into non-selective ion channels which alters the membrane potential [187-190]. The presence of palytoxin in seafood destined to human consumption is not regulated, but its high intraperitoneal toxicity and the reported toxic episodes in humans suggest the usefulness of detection methods.

Several enzyme-linked immunosorbent assays have been developed for the detection of palytoxin with sensitivities in the low $\mathrm{ng} / \mathrm{mL}$ range [177,191]. These ELISA assays can detect different palytoxins, but also non-toxic palytoxin derived compounds [191,192]. There are also several cell-based assays where hemolytic or cytotoxic activity of palytoxin is identified by neutralization with specific antibodies or ouabain [190,193]. However, these technologies have not been transferred to biosensor devices with integrated biological response and transduction detector. 


\section{Tetrodotoxin}

Tetrodotoxin (Figure 2) has been found in several species of tropical fish, gastropod mollusks, crabs and newts [194-197]. Although tetrodotoxin-contaminated fish, such as puffer fish, are found in tropical waters all over the world, poisoning episodes have been mainly described in Japan and other Asiatic countries [196,198], as the species that accumulate the toxin are not part of the diet in other parts of the globe, and therefore only sporadic poisonings have been described in Mexico, USA and Europe. This toxin of bacterial origin induces neurotoxic symptoms similar to the saxitoxin group. In spite of their different structures tetrodotoxin and saxitoxin are inhibitors of voltage gated $\mathrm{Na}^{+}$ channels, binding to site 1 of the $\alpha$-subunit [199]. The symptoms caused by tetrodotoxin poisoning include parestesias of several areas, nausea, vomiting, motor paralysis, incoordination, and even death by respiratory arrest $[195,198]$. The importation of puffer fish and other toxic species is not allowed in many countries, including the USA and Europe, and therefore no regulatory limits have been established $[100,200]$. The commercialization of certain tetrodotoxin-toxic species has been restricted in Asiatic countries [100].

The detection of tetrodotoxin, one of the most dangerous sea-born toxins, is essential for human health preservation in some countries. Several biosensor techniques have been developed that allow the detection of tetrodotoxin. One of the approaches uses an anti-tetrodotoxin specific antibody as the biological reporter and amperometric detection with a screen-printed electrode [33]. The format of the assay is an indirect competition assay where the amount of current generated by $p$-aminophenol, the product of the enzymatic activity of the alkaline phosphatase label of the specific antibody, is inhibited by the presence of tetrodotoxin in a sample that competes with the electrode immobilized tetrodotoxin. Another electrochemical biosensor technique for tetrodotoxin is based on differential pulse voltametry also with screen-prinded electrodes to measure the $p$-aminophenol product of alkaline phoshatase activity [201]. The design of this assay is also a competition immunoassay, but in this case the molecule labeled with the alkaline phosphatase is tetrodotoxin.

A tissue biosensor has been also developed with frog bladder membranes, which have a high concentration of $\mathrm{Na}^{+}$channels [202-204]. $\mathrm{A} \mathrm{Na}^{+}$specific electrode measures the transport of $\mathrm{Na}^{+}$ through the membrane and its dose-dependent inhibition by tetrodotoxin. Another tetrodotoxin biosensor based on inhibition of cell function has been designed using murine spinal cord neuronal networks cultured on microelectrode arrays [205]. The biological response is monitored as extracellular potentials. In this system, tetrodotoxin quantification was based on spike rate inhibition.

The performance of these biosensor assays with shellfish extracts has been reported only for the frog bladder biosensor. The neuronal network biosensor and the electrochemical immunosensors offer the advantage of portability. However, the portability of the biosensor does not ensure that in-field measurements can be performed if a simple enough sample preparation technique is not optimized for that purpose. An advantage of the biosensors based on functional responses is that they can be used to detect more than one compound with similar mechanisms of action, and usually the sensitivity is correlated with toxic potency. The frog bladder sensor has been demonstrated to be sensitive also for PSP toxins and it would be expected that the neuronal network biosensor could also detect this group of toxins. Actually, neuron-based biosensors could be used to detect many neurotoxins, acting as 
general detectors [206]. However, this promising technology will have to resolve some technical issues, such as the maintenance of neuron network cultures with all its logistic and economic problems.

All these techniques have a lower detection limit than the mouse bioassay for tetrodotoxin. However, as we said before, the performance of some of these biosensor assays with sample extracts is still to be tested.

Several ELISA assays have been developed as well for the detection of this toxin [33,201,207,208] some of them preparing the ground for the development of the electrochemical immunosensors mentioned above. A neuroblastoma culture assay in a microplate and a rapid hemolysis assay are also available for the detection of tetrodotoxin based on the inhibition of veratridine/ouabain-induced cell death [209]. Another recent technology that could be adapted in the future to detect tetrodotoxin and other marine neurotoxins using biosensors is the incorporation in lipid bilayers of recombinant human voltage-gated sodium channels [210].

\section{Concluding Remarks}

There have been great advances in the use of biosensors for marine toxin detection and the future is still more promising. The current situation is that for most groups of toxins there are biosensor technologies with enough sensitivity to comply with the regulatory limits. However, none of these methods has been validated and/or accepted as an alternative to the mouse bioassay. Actually, in most cases these techniques would be good tools to be used at least as screening methods in order to reduce the number of animal bioassays.

In general, biosensor technologies have some advantages versus analytical methods and animal bioassays that include low cost, ease-of-use, speed, no need of highly trained lab personnel and automation, most of them with very good reproducibility and robustness. Moreover, these methods do not entail legal or ethical issues related to the use of laboratory animals. The evaluation of the toxicity of a sample with biosensor-based techniques does not require the use of a toxin standard of every compound of a toxin group, just a representative member would suffice, which is one of the more important drawbacks of analytical methods, since certified standards for many marine toxin analogues are not available or easy to produce.

In the field of immunosensors, it is important to keep in mind that the ability of the antibodies to detect the different members of a toxin group is based in the immune response of a host to an antigen (usually a protein-coupled toxin), which is not related to the toxic potency of these compounds. Antibodies with a good correlation of cross-reactivity and toxic potency are rarely obtained, and when it happens it is mainly for toxin groups with a reduced number of analogues. As a consequence, the quantification of the toxin content of a sample by antibody-based methods does not often reflect accurately its toxicity. Sometimes the results of immunoassays are reported as equivalents of a representative toxin of the group, in the same way the regulatory limit is established, however the regulatory limit refers to toxic equivalence, so the use of that terminology in immunoassays/sensors is misleading. In spite of these disadvantages, these assays are sensitive, reliable, robust, easy to perform, portable techniques and therefore worthy alternatives for screening purposes. Additionally, the search 
for new, improved antibodies has already produced detection tools with a very good correlation between toxicity and cross-reactivity, such as in the case of okadaic acid immunosensors [31].

Functional and biological receptor-based assays/sensors usually provide a better evaluation of sample toxicity, since the measurement is based on the mechanism of action of the toxin. However, the robustness and portability of functional/receptor-based techniques is not as good as for immunosensors, because receptors and cells are usually more labile than antibodies. Some practical issues have to be overcome before an extended use of cell-based sensors such as the need to maintain cell cultures. The use of receptors in an extended technique for the detection of some groups of toxins is really feasible these days. For example, the reagents needed for the cyclic imine receptor-based assay have good stability in laboratory storage conditions [126].

\section{Acknowledgements}

This work was funded with the following grants: From Ministerio de Ciencia y Tecnología, Spain: AGL2006-08439/ALI, AGL2007-60946/ALI. From Xunta de Galicia, Spain: GRC 30/2006, and PGIDT07CSA012261PR, PGDIT 07MMA006261PR, 2008/CP389 (EPITOX, Consellería de Innovación e Industria, programa IN.CI.TE.). From EU VIth Frame Program: IP FOOD-CT-2004-06988 (BIOCOP), and CRP 030270-2 (SPIES-DETOX). From EU VIIth Frame Program: 211326-CP (CONffIDENCE); STC-CP2008-1-555612 (Atlantox).

\section{References and Notes}

1. Hallegraeff, G.M. A review of harmful algal blooms and their apparent global increase. Phycologia 1993, 32, 79-99.

2. Rodriguez-Velasco, M.L. Toxin monitoring programs and regulatory review. In Seafood and freshwater toxins: pharmacology, physiology and detection, 2nd ed.; Botana, L.M., Ed.; CRC Press: Boca Raton, FL, USA, 2008; pp. 919-932.

3. Hoagland, P; Scatasta, S. The economic effects of harmful algal blooms. In Ecology of harmful algae; Graneli, E; Turner, J., Ed.; Ecology Studies Series; Springer-Verlag: Dordrecht, The Netherlands, 2006.

4. Vieites, J.M.; Cabado, A.G. Incidence of marine toxins on industrial activity. In Seafood and freshwater toxins. Pharmacology, physiology and detection; Botana, L.M., Ed.; CRC Press (Taylor and Francis Group): Boca Raton, FL, USA, 2008; pp. 899-916.

5. Sauer, U.G. Animal vs. non-animal tests for the monitoring of marine biotoxins in the EU. Altex 2005, 22, 19-24.

6. Holland, P. Analysis of marine toxins-techniques, method validation, calibration standards and screening methods. In Seafood and freshwater toxins: pharmacology, physiology and detection, 2nd ed.; Botana, L.M., Ed.; CRC Press: Boca Raton, FL, USA, 2008; pp. 21-49.

7. Combes, R.D. The mouse bioassay for diarrhetic shellfish poisoning: a gross misuse of laboratory animals and of scientific methodology. Altern. Lab. Anim. 2003, 31, 595-610. 
8. EC. Council Directive 86/609/EEC of November 24, 1986 on the approximation of laws, regulation and administrative provisions of the Member States regarding the protection of animals used for experimental and other scientific purposes. Offic. J. L Counc. Eur. Communities 1986, 358, 1-29.

9. AOAC, Official method 959.08. Paralytic shellfish poison. Biological method. in AOAC Official Methods of Analysis, 18th ed.; International, A.: Gaithersburg, MD, USA, 2005.

10. EC. Commision Regulation (EC) No 1664/2006 of November 6, 2006 amending Regulation (EC) No 2074/2005 as regards implementing measures for certain products of animal origin intended for human consumption and repealing certain implementing measures. Offic. J. $L$ Counc. Eur. Communities 2006, 320, 13-45.

11. Kleivdal, H.; Kristiansen, S.I.; Nilsen, M.V.; Goksoyr, A.; Briggs, L.; Holland, P.; McNabb, P. Determination of domoic acid toxins in shellfish by biosense ASP ELISA--a direct competitive enzyme-linked immunosorbent assay: collaborative study. J. AOAC Int. 2007, 90, 1011-1027.

12. Amine, A.; Mohammadi, H.; Bourais, I.; Palleschi, G. Enzyme inhibition-based biosensors for food safety and environmental monitoring. Biosens. Bioelectron. 2006, 21, 1405-1423.

13. Baeumner, A.J. Biosensors for environmental pollutants and food contaminants. Anal. Bioanal. Chem. 2003, 377, 434-45.

14. Luong, J.H.; Bouvrette, P.; Male, K.B. Developments and applications of biosensors in food analysis. Trend. Biotechnol. 1997, 15, 369-77.

15. Conroy, P.J.; Hearty, S.; Leonard, P.; O'Kennedy, R.J. Antibody production, design and use for biosensor-based applications. Semin. Cell Dev. Biol. 2009, 20, 10-26.

16. Banerjee, P; Bhunia, A.K. Mammalian cell-based biosensors for pathogens and toxins. Trends Biotechnol. 2009, 27, 179-88.

17. Gestal-Otero, J.J. Epidemiologic impact of diarrheic toxins. In Seafood and freshwater toxins: pharmacology, physiology and detection, 2nd ed.; Botana, L.M., Ed.; CRC Press: New York, NY, USA, 2008; pp. 53-75.

18. Lee, J.S.; Igarashi, T.; Fraga, S.; Dahl, E.; Hovgaard, P.; Yasumoto, T. Determination of diarrhetic shellfish toxins in various dinoflagellate species. J. Appl. Phycol. 1989, 1, 147-152.

19. Morton, S.L; Tindall, D.R. Determination of okadaic acid content of dinoflagellate cells: a comparison of the HPLC-fluorescent method and two monoclonal antibody ELISA test kits. Toxicon 1996, 34, 947-54.

20. Zhou, J; Fritz, L.; Ultrastructure of two toxic marine dinoflagellates, Prorocentrum lima and Prorocentrum maculosum. Phycologia 1993, 32, 444-450.

21. Dawson, J.F; Holmes, C.F.; Molecular mechanisms underlying inhibition of protein phosphatases by marine toxins. Front. Biosci. 1999, 4, D646-58.

22. Honkanen, R.E.; Codispoti, B.A.; Tse, K.; Boynton, A.L.; Honkanan, R.E. Characterization of natural toxins with inhibitory activity against serine/threonine protein phosphatases. Toxicon 1994, 32, 339-350.

23. Yasumoto, T.; Oshima, Y.; Yamaguchi, M.; Occurence of a new type of shellfish poisoning in the Tohuku district. Bull. Jap. Soc. Sci. Fish. 1978, 44, 1249-1255. 
24. EC. Regulation (EC) No 853/2004 of the European Parliament and of the Council of April 29, 2004 laying down specific hygiene rules for food of animal origin. Offic. J. L Counc. Eur. Communities 2004, 139, 55.

25. EC. Comission Regulation (EC) No 2074/2005 of December 5, 2005. Offic. J. L Counc. Eur. Communities 2005, 338, 27-59.

26. Fujiki, H; Suganuma, M. Tumor promotion by inhibitors of protein phosphatases 1 and 2A: the okadaic acid class of compounds. Adv. Cancer. Res. 1993, 61, 143-94.

27. Fujiki, H.; Suganuma, M.; Suguri, H.; Yoshizawa, S.; Takagi, K.; Uda, N.; Wakamatsu, K.; Yamada, K.; Murata, M.; Yasumoto, T. Diarrhetic shellfish toxin, dinophysistoxin-1, is a potent tumor promoter on mouse skin. Jpn. J. Cancer. Res. 1988, 79, 1089-1093.

28. Tang, A.X.J.; Pravda, M.; Guilbault, G.G.; Piletsky, S.; Turner, A.P.F. Immunosensor for okadaic acid using quartz crystal microbalance. Anal. Chim. Acta 2002, 471, 33-40.

29. Marquette, C.A.; Coulet, P.R.; Blum, L.J. Semi-automated membrane based chemiluminescent immunosensor for flow injection analysis of okadaic acid in mussels. Anal. Chim. Acta 1999, 398, 173-182.

30. Llamas, N.M.; Stewart, L.; Fodey, T.; Higgins, H.C.; Velasco, M.L.; Botana, L.M.; Elliott, C.T. Development of a novel immunobiosensor method for the rapid detection of okadaic acid contamination in shellfish extracts. Anal. Bioanal. Chem. 2007, 389, 581-7.

31. Stewart, L.D.; Elliott, C.T.; Walker, A.D.; Curran, R.M.; Connolly, L. Development of a monoclonal antibody binding okadaic acid and dinophysistoxins-1, -2 in proportion to their toxicity equivalence factors. Toxicon 2009, 54, 491-8.

32. Campas, M.; de la Iglesia, P.; Le Berre, M.; Kane, M.; Diogene, J.; Marty, J.L. Enzymatic recycling-based amperometric immunosensor for the ultrasensitive detection of okadaic acid in shellfish. Biosens. Bioelectron. 2008, 24, 716-22.

33. Kreuzer, M.P.; Pravda, M.; O'Sullivan, C.K.; Guilbault, G.G. Novel electrochemical immunosensors for seafood toxin analysis. Toxicon 2002, 40, 1267-74.

34. Tang, A.X.J.; Kreuzer, M.; Lehane, M.; Pravda, M.; Guilbault, G.G. Immunosensor for the Determination of Okadaic Acid Based on Screen-Printed Electrode Int. J. Environ. Anal. Chem. 2003, 83, 663-670.

35. Campas, M; Marty, J.L. Enzyme sensor for the electrochemical detection of the marine toxin okadaic acid. Anal. Chim. Acta 2007, 605, 87-93.

36. Volpe, G.; Cotroneo, E.; Moscone, D.; Croci, L.; Cozzi, L.; Ciccaglioni, G.; Palleschi, G. A bienzyme electrochemical probe for flow injection analysis of okadaic acid based on protein phosphatase-2A inhibition: an optimization study. Anal. Biochem. 2009, 385, 50-56.

37. Kreuzer, M.P.; O'Sullivan, C.K.; Guilbault, G.G. Development of an ultrasensitive immunoassay for rapid measurement of okadaic acid and its isomers. Anal. Chem. 1999, 71, 4198-4202.

38. Della Loggia, R.; Sosa, S.; Tubaro, A.; Methodological improvement of the protein phosphatase inhibition assay for the detection of okadaic acid in mussels. Nat. Toxins 1999, 7, 387-391.

39. Tubaro, A.; Florio, C.; Luxich, E.; Sosa, S.; Della Loggia, R.; Yasumoto, T.; A protein phosphatase 2A inhibition assay for a fast and sensitive assessment of okadaic acid contamination in mussels. Toxicon 1996, 34, 743-752. 
40. Vieytes, M.R.; Fontal, O.I.; Leira, F.; Baptista de Sousa, J.M.; Botana, L.M.; A fluorescent microplate assay for diarrheic shellfish toxins. Anal. Biochem. 1997, 248, 258-64.

41. Mountfort, D.O.; Suzuki, T.; Truman, P. Protein phosphatase inhibition assay adapted for determination of total DSP in contaminated mussels. Toxicon 2001, 39, 383-90.

42. Cañete, E; Diogène, J. Comparative study of the use of neuroblastoma cells (Neuro-2a) and neuroblastomaxglioma hybrid cells (NG108-15) for the toxic effect quantification of marine toxins. Toxicon 2008, 52, 541-550..

43. Leira, F.; Alvarez, C.; Cabado, A.G.; Vieites, J.M.; Vieytes, M.R.; Botana, L.M. Development of a $\mathrm{F}$ actin-based live-cell fluorimetric microplate assay for diarrhetic shellfish toxins. Anal. Biochem. 2003, 317, 129-135.

44. Tubaro, A.; Florio, C.; Luxich, E.; Vertua, R.; Della Loggia, R.; Yasumoto, T. Suitability of the MTT-based cytotoxicity assay to detect okadaic acid contamination of mussels. Toxicon 1996, 34, 965-974.

45. Gonzalez, J.C.; Leira, F.; Vieytes, M.R.; Vieites, J.M.; Botana, A.M.; Botana, L.M. Development and validation of a high-performance liquid chromatographic method using fluorimetric detection for the determination of the diarrhetic shellfish poisoning toxin okadaic acid without chlorinated solvents. J. Chromatogr. A 2000, 876, 117-25.

46. Quilliam, M.A. Analysis of diarrhetic shellfish poisoning toxins in shellfish tissue by liquid chromatography with fluorometric and mass spectrometric detection. J. AOAC Int. 1995, 78, 555-70.

47. McNabb, P.; Selwood, A.I.; Holland, P.T.; Aasen, J.; Aune, T.; Eaglesham, G.; Hess, P.; Igarishi, M.; Quilliam, M.; Slattery, D.; Van de Riet, J.; Van Egmond, H.; Van den Top, H.; Yasumoto, T. Multiresidue method for determination of algal toxins in shellfish: single-laboratory validation and interlaboratory study. J. AOAC Int. 2005, 88,761-72.

48. Gerssen, A.; McElhinney, M.A.; Mulder, P.P.; Bire, R.; Hess, P.; de Boer, J. Solid phase extraction for removal of matrix effects in lipophilic marine toxin analysis by liquid chromatography-tandem mass spectrometry. Anal. BioAnal. Chem. 2009, 394, 1213-1226.

49. These, A.; Scholz, J.; Preiss-Weigert, A. Sensitive method for the determination of lipophilic marine biotoxins in extracts of mussels and processed shellfish by high-performance liquid chromatography-tandem mass spectrometry based on enrichment by solid-phase extraction. $J$. Chromatogr. A 2009, 1216, 4529-4538.

50. Miles, C.O. Pectenotoxins. in Phycotoxins. Chemistry and Biochemistry; Botana, L.M., Ed.; Blackwell Publishing: Oxford, UK, 2007; pp. 159-186.

51. Vilariño, N; Espiña, B. Pharmacology of pectenotoxins. In Seafood and freshwater toxins: pharmacology, physiology and detection, 2nd ed.; Botana, L.M., Ed.; CRC Press: Boca Raton, FL, USA, 2008; pp. 361-369.

52. Miles, C.O.; Wilkins, A.L.; Munday, R.; Dines, M.H.; Hawkes, A.D.; Briggs, L.R.; Sandvik, M.; Jensen, D.J.; Cooney, J.M.; Holland, P.T.; Quilliam, M.A.; MacKenzie, A.L.; Beuzenberg, V.; Towers, N.R. Isolation of pectenotoxin-2 from Dinophysis acuta and its conversion to pectenotoxin-2 seco acid, and preliminary assessment of their acute toxicities. Toxicon 2004, 43, $1-9$. 
53. Suzuki, T.; Walter, J.A.; LeBlanc, P.; MacKinnon, S.; Miles, C.O.; Wilkins, A.L.; Munday, R.; Beuzenberg, V.; MacKenzie, A.L.; Jensen, D.J.; Cooney, J.M.; Quilliam, M.A. Identification of pectenotoxin-11 as 34S-hydroxypectenotoxin-2, a new pectenotoxin analogue in the toxic dinoflagellate Dinophysis acuta from New Zealand. Chem. Res. Toxicol. 2006, 19, 310-318.

54. Ares, I.R.; Louzao, M.C.; Espina, B.; Vieytes, M.R.; Miles, C.O.; Yasumoto, T.; Botana, L.M. Lactone ring of pectenotoxins: a key factor for their activity on cytoskeletal dynamics. Cell. Physiol. Biochem. 2007, 19, 283-292.

55. Espina, B.; Louzao, M.C.; Ares, I.R.; Cagide, E.; Vieytes, M.R.; Vega, F.V.; Rubiolo, J.A.; Miles, C.O.; Suzuki, T.; Yasumoto, T.; Botana, L.M. Cytoskeletal toxicity of pectenotoxins in hepatic cells. Br. J. Pharmacol. 2008, 155, 934-944.

56. Spector, I.; Braet, F.; Shochet, N.R.; Bubb, M.R. New anti-actin drugs in the study of the organization and function of the actin cytoskeleton. Microsc. Res. Tech. 1999, 47, 18-37.

57. Zhou, Z.H.; Komiyama, M.; Terao, K.; Shimada, Y. Effects of pectenotoxin-1 on liver cells in vitro. Nat. Toxins. 1994, 2, 132-135.

58. Fladmark, K.E.; Serres, M.H.; Larsen, N.L.; Yasumoto, T.; Aune, T.; Doskeland, S.O. Sensitive detection of apoptogenic toxins in suspension cultures of rat and salmon hepatocytes. Toxicon 1998, 36, 1101-1114.

59. Sasaki, K.; Takizawa, A.; Tubaro, A.; Sidari, L.; Loggia, R.D.; Yasumoto, T. Fluorometric analysis of pectenotoxin-2 in microalgal samples by high performance liquid chromatography. Nat. Toxins. 1999, 7, 241-6.

60. Quilliam, M.A. The role of chromatography in the hunt for red tide toxins. J. Chromatogr. A 2003, 1000, 527-48.

61. Paz, B.; Daranas, A.H.; Norte, M.; Riobo, P.; Franco, J.M.; Fernandez, J.J. Yessotoxins, a group of marine polyether toxins: an overview. Mar. Drugs. 2008, 6, 73-102.

62. Draisci, R.; Ferretti, E.; Palleschi, L.; Marchiafava, C.; Poletti, R.; Milandri, A.; Ceredi, A.; Pompei, M. High levels of yessotoxin in mussels and presence of yessotoxin and homoyessotoxin in dinoflagellates of the Adriatic Sea. Toxicon 1999, 37, 1187-1193.

63. Rhodes, L.L.; McNabb, P.; De Salas, M.; Briggs, L.; Beuzenberg, V.; Gladstone, M. Yessotoxin production by Gonyaulax spinifera. Harmful Algae 2006, 5, 148-15

64. Satake, M.; MacKenzie, L.; Yasumoto, T.; Identification of Protoceratium reticulatum as the biogenetic origin of yessotoxin. Nat. Toxins. 1997, 5, 164-7.

65. FAO/WHOI/IOC. Report of the Joint FAO/IOC/WHO ad hoc Expert Consultation on Biotoxins in Bivalve Molluscs. Oslo, Norway, 2004.

66. Aune, T.; Sorby, R.; Yasumoto, T.; Ramstad, H.; Landsverk, T. Comparison of oral and intraperitoneal toxicity of yessotoxin towards mice. Toxicon 2002, 40, 77-82.

67. Tubaro, A.; Sosa, S.; Carbonatto, M.; Altinier, G.; Vita, F.; Melato, M.; Satake, M.; Yasumoto, T. Oral and intraperitoneal acute toxicity studies of yessotoxin and homoyessotoxins in mice. Toxicon 2003, 41, 783-792.

68. Ogino, H.; Kumagai, M.; Yasumoto, T. Toxicologic evaluation of yessotoxin. Nat. Toxins. 1997, 5, 255-259. 
69. Fonfria, E.S.; Vilarino, N.; Vieytes, M.R.; Yasumoto, T.; Botana, L.M. Feasibility of using a surface plasmon resonance-based biosensor to detect and quantify yessotoxin. Anal. Chim. Acta 2008, 617, 167-170.

70. Pazos, M.J.; Alfonso, A.; Vieytes, M.R.; Yasumoto, T.; Botana, L.M. Kinetic analysis of the interaction between yessotoxin and analogues and immobilized phosphodiesterases using a resonant mirror optical biosensor. Chem. Res. Toxicol. 2005, 18, 1155-1160.

71. Pazos, M.J.; Alfonso, A.; Vieytes, M.R.; Yasumoto, T.; Vieites, J.M.; Botana, L.M. Resonant mirror biosensor detection method based on yessotoxin-phosphodiesterase interactions. Anal. Biochem. 2004, 335, 112-8.

72. Mouri, R.; Oishi, T.; Torikai, K.; Ujihara, S.; Matsumori, N.; Murata, M.; Oshima, Y. Surface plasmon resonance-based detection of ladder-shaped polyethers by inhibition detection method. Bioorg. Med. Chem. Lett. 2009, 19, 2824-2828.

73. Alfonso, A.; Vieytes, M.R.; Yasumoto, T.; Botana, L.M. A rapid microplate fluorescence method to detect yessotoxins based on their capacity to activate phosphodiesterases. Anal. Biochem. 2004, 326, 93-99.

74. Alfonso, C.; Alfonso, A.; Vieytes, M.R.; Yasumoto, T.; Botana, L.M. Quantification of yessotoxin using the fluorescence polarization technique and study of the adequate extraction procedure. Anal. Biochem. 2005, 344, 266-274.

75. Pierotti, S.; Albano, C.; Milandri, A.; Callegari, F.; Poletti, R.; Rossini, G.P. A slot blot procedure for the measurement of yessotoxins by a functional assay. Toxicon 2007, 49, 36-45.

76. Pierotti, S.; Malaguti, C.; Milandri, A.; Poletti, R.; Paolo Rossini, G. Functional assay to measure yessotoxins in contaminated mussel samples. Anal. Biochem. 2003, 312, 208-216.

77. Ronzitti, G.; Hess, P.; Rehmann, N.; Rossini, G.P. Azaspiracid-1 alters the E-cadherin pool in epithelial cells. Toxicol Sci 2007, 95, 427-435.

78. Briggs, L.R.; Miles, C.O.; Fitzgerald, J.M.; Ross, K.M.; Garthwaite, I.; Towers, N.R. Enzyme-linked immunosorbent assay for the detection of yessotoxin and its analogues. J. Agric. Food Chem. 2004, 52, 5836-5842.

79. Garthwaite, I.; Ross, K.M.; Miles, C.O.; Briggs, L.R.; Towers, N.R.; Borrell, T.; Busby, P. Integrated enzyme-linked immunosorbent assay screening system for amnesic, neurotoxic, diarrhetic, and paralytic shellfish poisoning toxins found in New Zealand. J. AOAC Int. 2001, 84, 1643-1648.

80. de la Iglesia, P.; Gago-Martinez, A. Determination of yessotoxins and pectenotoxins in shellfish by capillary electrophoresis-electrospray ionization-mass spectrometry. Food Addit. Contam. Part A Chem. Anal. Control. Expo. Risk Assess. 2009, 26, 221-228.

81. Gago-Martinez, A.; Pineiro, N.; Aguete, E.C.; Vaquero, E.; Nogueiras, M.; Leao, J.M.; Rodriguez-Vazquez, J.A.; Dabek-Zlotorzynska, E. Further improvements in the application of high-performance liquid chromatography, capillary electrophoresis and capillary electrochromatography to the analysis of algal toxins in the aquatic environment. J. Chromatogr. A 2003, 992, 159-168.

82. Yasumoto, T; Takizawa, A. Fluorometric measurement of yessotoxins in shellfish by high-pressure liquid chromatography. Biosci. Biotechnol. Biochem. 1997, 61, 1775-1777. 
83. McMahon, T; Silke, J.; Winter toxicity of unknown aetiology in mussels. Harmful Algae News 1996, 14, 2.

84. Ofuji, K.; Satake, M.; McMahon, T.; James, K.J.; Naoki, H.; Oshima, Y.; Yasumoto, T. Structures of azaspiracid analogs, azaspiracid-4 and azaspiracid-5, causative toxins of azaspiracid poisoning in Europe. Biosci. Biotechnol. Biochem. 2001, 65, 740-742.

85. Ofuji, K.; Satake, M.; McMahon, T.; Silke, J.; James, K.J.; Naoki, H.; Oshima, Y.; Yasumoto, T. Two analogs of azaspiracid isolated from mussels, Mytilus edulis, involved in human intoxication in Ireland. Nat. Toxins. 1999, 7, 99-102.

86. Rehmann, N.; Hess, P.; Quilliam, M.A. Discovery of new analogs of the marine biotoxin azaspiracid in blue mussels (Mytilus edulis) by ultra-performance liquid chromatography/tandem mass spectrometry. Rapid Commun. Mass. Spectrom. 2008, 22, 549-558.

87. Satake, M.; Ofuji, K.; Naoki, H.; James, K.; Furey, A.; McMahon, T.; Silke, J.; Yasumoto, T. Azaspiracid, a new marine toxin having unique spiro ring assemblies, isolated from Irish Mussels, Mytilus edulis. J. Am. Chem. Soc. 1998, 120, 9967-9968.

88. James, K.J.; Sierra, M.D.; Lehane, M.; Brana Magdalena, A.; Furey, A. Detection of five new hydroxyl analogues of azaspiracids in shellfish using multiple tandem mass spectrometry. Toxicon 2003, 41, 277-283.

89. James, K.J.; Moroney, C.; Roden, C.; Satake, M.; Yasumoto, T.; Lehane, M.; Furey, A. Ubiquitous 'benign' alga emerges as the cause of shellfish contamination responsible for the human toxic syndrome, azaspiracid poisoning. Toxicon 2003, 41, 145-151.

90. James, K.J.; Furey, A.; Lehane, M.; Ramstad, H.; Aune, T.; Hovgaard, P.; Morris, S.; Higman, W.; Satake, M.; Yasumoto, T. First evidence of an extensive northern European distribution of azaspiracid poisoning (AZP) toxins in shellfish. Toxicon 2002, 40, 909-915.

91. Magdalena, A.B.; Lehane, M.; Krys, S.; Fernandez, M.L.; Furey, A.; James, K.J. The first identification of azaspiracids in shellfish from France and Spain. Toxicon 2003, 42, 105-108.

92. Aasen, J.; Samdal, I.A.; Miles, C.O.; Dahl, E.; Briggs, L.R.; Aune, T. Yessotoxins in Norwegian blue mussels (Mytilus edulis): uptake from Protoceratium reticulatum, metabolism and depuration. Toxicon 2005, 45, 265-272.

93. Elgarch, A.; Vale, P.; Rifai, S.; Fassouane, A. Detection of diarrheic shellfish poisoning and azaspiracid toxins in Moroccan mussels: comparison of the LC-MS method with the commercial immunoassay kit. Mar. Drugs. 2008, 6, 587-594.

94. Forsyth, C.J.; Xu, J.; Nguyen, S.T.; Samdal, I.A.; Briggs, L.R.; Rundberget, T.; Sandvik, M.; Miles, C.O. Antibodies with broad specificity to azaspiracids by use of synthetic haptens. J. Am. Chem. Soc. 2006, 128, 15114-15116.

95. Frederick, M.O.; De Lamo Marin, S.; Janda, K.D.; Nicolaou, K.C.; Dickerson, T.J. Monoclonal antibodies with orthogonal azaspiracid epitopes. Chembiochem 2009, 10, 1625-1629.

96. Furey, A.; Garcia, J.; O'Callaghan, K.; Lehane, M.; Férnandez, M.; James, K.J. Brevetoxins: structure, toxicology and origin. In Phycotoxins: chemistry and biochemistry. Botana, L.M., Ed.; Blackwell Publishing: Ames, IA, USA, 2007; pp. 19-46.

97. Magaña, H.A.; Contreras, C.; Villareal, T.A. A historical assessment of Karenia brevis in the western Gulf of Mexico. Harmful Algae 2003, 2, 163-171. 
98. Nozawa, A.; Tsuji, K.; Ishida, H. Implication of brevetoxin B1 and PbTx-3 in neurotoxic shellfish poisoning in New Zealand by isolation and quantitative determination with liquid chromatography-tandem mass spectrometry. Toxicon 2003, 42, 91-103.

99. Van Dolah, F.M. Diversity of marine and freswater algal toxins. In Seafood and freswater toxins: pharmacology, physiology and detection; Botana, L.M., Ed.; Marcel Dekker: New York, NY, USA, 2000; pp. 19-43.

100. Gessner, B.D; McLaughlin, J.B. Epidemiologic impact of toxic episodes: neurotoxic toxins. in Seafood and freshwater toxins: pharmacology, physiology and detection. 2nd ed.; Botana, L.M., Ed.; CRC Press: Boca Raton, FL, USA, 2008; pp. 77-103.

101. Bossart, G.D.; Baden, D.G.; Ewing, R.Y.; Roberts, B.; Wright, S.d. Brevetoxicosis in manatees (Trichechus manatus latirostris) from the 1996 epizootic: gross, histologic, and immunohistochemical features. Toxicol. Pathol. 1998, 26, 276-282.

102. Flewelling, L.J.; Naar, J.P.; Abbott, J.P.; Baden, D.G.; Barros, N.B.; Bossart, G.D.; Bottein, M.Y.; Hammond, D.G.; Haubold, E.M.; Heil, C.A.; Henry, M.S.; Jacocks, H.M.; Leighfield, T.A.; Pierce, R.H.; Pitchford, T.D.; Rommel, S.A.; Scott, P.S.; Steidinger, K.A.; Truby, E.W.; Van Dolah, F.M.; Landsberg, J.H. Brevetoxicosis: red tides and marine mammal mortalities. Nature 2005, 435, 755-756.

103. Kreuder, C.; Mazet, J.A.; Bossart, G.D.; Carpenter, T.E.; Holyoak, M.; Elie, M.S.; Wright, S.D. Clinicopathologic features of suspected brevetoxicosis in double-crested cormorants (Phalacrocorax auritus) along the Florida Gulf Coast. J. Zoo Wildl. Med. 2002, 33, 8-15.

104. APHA, Method for Ptychodiscus brevis toxins. in Laboratory procedures for the examination of seawater and shellfish, 5th ed.; American Public Health Association: Washington, D. C., USA, 1985; pp. 64-80.

105. Watkins, S.M.; Reich, A.; Fleming, L.E.; Hammond, R. Neurotoxic shellfish poisoning. Mar. Drugs. 2008, 6, 431-455.

106. Kulagina, N.V.; Mikulski, C.M.; Gray, S.; Ma, W.; Doucette, G.J.; Ramsdell, J.S.; Pancrazio, J.J. Detection of marine toxins, brevetoxin-3 and saxitoxin, in seawater using neuronal networks. Environ. Sci. Technol. 2006, 40, 578-583.

107. Twiner, M.J.; Bottein Dechraoui, M.Y.; Wang, Z.; Mikulski, C.M.; Henry, M.S.; Pierce, R.H.; Doucette, G.J. Extraction and analysis of lipophilic brevetoxins from the red tide dinoflagellate Karenia brevis. Anal. Biochem. 2007, 369, 128-135.

108. Baden, D.G.; Mende, T.J.; Walling, J.; Schultz, D.R. Specific antibodies directed against toxins of Ptychodiscus brevis (Florida's red tide dinoflagellate). Toxicon 1984, 22, 783-789.

109. Poli, M.A.; Rein, K.S.; Baden, D.G. Radioimmunoassay for PbTx-2-type brevetoxins: epitope specificity of two anti-PbTx sera. J. AOAC Int. 1995, 78, 538-542.

110. Baden, D.G.; Melinek, R.; Sechet, V.; Trainer, V.L.; Schultz, D.R.; Rein, K.S.; Tomas, C.R.; Delgado, J.; Hale, L. Modified immunoassays for polyether toxins: implications of biological matrixes, metabolic states, and epitope recognition. J. AOAC Int. 1995, 78, 499-508.

111. Naar, J.; Bourdelais, A.; Tomas, C.; Kubanek, J.; Whitney, P.L.; Flewelling, L.; Steidinger, K.; Lancaster, J.; Baden, D.G. A competitive ELISA to detect brevetoxins from Karenia brevis (formerly Gymnodinium breve) in seawater, shellfish, and mammalian body fluid. Environ. Health Perspect. 2002, 110, 179-185. 
112. Louzao, M.C.; Vieytes, M.R.; Yasumoto, T.; Botana, L.M. Detection of sodium channel activators by a rapid fluorimetric microplate assay. Chem. Res. Toxicol. 2004, 17, 572-578.

113. Hua, Y.; Lu, W.; Henry, M.S.; Pierce, R.H.; Cole, R.B. On-line high-performance liquid chromatography-electrospray ionization mass spectrometry for the determination of brevetoxins in "red tide" algae. Anal. Chem. 1995, 67, 1815-1823.

114. Shea, D. Analysis of brevetoxins by micellar electrokinetic capillary chromatography and laser-induced fluorescence detection. Electrophoresis 1997, 18, 277-283.

115. Molgó, J.; Girard, E.; Benoit, E. Cyclic imines: an insight into this emerging group of bioactive marine toxins. In Phycotoxins: chemistry and biochemistry. Botana, L.M., Ed.; Blackwell Publishing: Ames, IA, USA, 2007; pp. 319-335.

116. Munday, R.; Towers, N.R.; Mackenzie, L.; Beuzenberg, V.; Holland, P.T.; Miles, C.O. Acute toxicity of gymnodimine to mice. Toxicon 2004, 44, 173-178.

117. Kharrat, R.; Servent, D.; Girard, E.; Ouanounou, G.; Amar, M.; Marrouchi, R.; Benoit, E.; Molgo, J. The marine phycotoxin gymnodimine targets muscular and neuronal nicotinic acetylcholine receptor subtypes with high affinity. J. Neurochem. 2008, 107, 952-963.

118. Molgó, J.; Amar, M.; Aráoz, R.; Benoit, E.; Silveira, P.; Schlumberger, S.; Lecardeur, S.; Servent, D. The dinoflagellate toxin 13-Desmethyl Spirolide-C broadly targets muscle and neuronal nicotinic acetylcholine receptors with high affinity. In 16th European Section Meeting of the International Society on Toxinolog, Leuven, Belgium, September 7-10, 2008.

119. Cembella, A; Krock, B. Cyclic imine toxins: chemistry, biogeography, biosynthesis and pharmacology. In Seafood and freshwater toxins: pharmacology, physiology and detection, 2nd ed.; Botana, L.M., Ed.; CRC Press: Boca Raton, FL, USA, 2008.

120. Munday, R. Toxicology of Cyclic Imines: Gymnodimine, Spirolides, Pinnatoxins, Pteriatoxins, Prorocentrolide, Spiro-prorocentrimine and Symbioimines. In Seafood and freshwater toxins: pharmacology, physiology and detection, 2nd ed.; Botana, L.M., Ed.; CRC Press: Boca Raton, FL, USA, 2008; pp. 581-594.

121. Aasen, J.; MacKinnon, S.L.; LeBlanc, P.; Walter, J.A.; Hovgaard, P.; Aune, T.; Quilliam, M.A. Detection and identification of spirolides in norwegian shellfish and plankton. Chem. Res. Toxicol. 2005, 18, 509-515.

122. Ciminiello, P.; Dell'Aversano, C.; Fattorusso, E.; Magno, S.; Tartaglione, L.; Cangini, M.; Pompei, M.; Guerrini, F.; Boni, L.; Pistocchi, R. Toxin profile of Alexandrium ostenfeldii (Dinophyceae) from the Northern Adriatic Sea revealed by liquid chromatography-mass spectrometry. Toxicon 2006, 47, 597-604.

123. Hu, T.; Burton, I.W.; Cembella, A.D.; Curtis, J.M.; Quilliam, M.A.; Walter, J.A.; Wright, J.L. Characterization of spirolides a, c, and 13-desmethyl c, new marine toxins isolated from toxic plankton and contaminated shellfish. J. Nat. Prod. 2001, 64, 308-312.

124. Stirling, D.J. Survey of historical New Zealand shellfish samples for accumulation of gymnodimine. N. Z. J. Mar. Freshwater Res. 2001, 35, 851-857.

125. Fux, E.; McMillan, D.; Bire, R.; Hess, P. Development of an ultra-performance liquid chromatography-mass spectrometry method for the detection of lipophilic marine toxins. $J$. Chromatogr. A 2007, 1157, 273-280. 
126. Vilariño, N.; Fonfria, E.S.; Molgo, J.; Araoz, R.; Botana, L.M. Detection of Gymnodimine-A and 13-Desmethyl C Spirolide Phycotoxins by Fluorescence Polarization. Anal. Chem. 2009, 81, 2708-2714

127. Van Dolah, F.M. Marine algal toxins: origins, health effects, and their increased occurrence. Environ. Health Perspect. 2000, 108, 133-141.

128. Cestele, S; Catterall, W.A. Molecular mechanisms of neurotoxin action on voltage-gated sodium channels. Biochimie 2000, 82, 883-892

129. Noda, M.; Suzuki, H.; Numa, S.; Stuhmer, W. A single point mutation confers tetrodotoxin and saxitoxin insensitivity on the sodium channel II. FEBS Lett. 1989, 259,213-216.

130. Catterall, W.A. Neurotoxins that act on voltage-sensitive sodium channels in excitable membranes. Annu. Rev. Pharmacol. Toxicol. 1980, 20, 15-43.

131. Kao, C.Y. Tetrodotoxin, saxitoxin and their significance in the study of excitation phenomena. Pharmacol. Rev. 1966, 18, 997-1049

132. Hallegraeff, G.M. Harmful algal blooms: a global overview. In Manual on Harmful Marine Microalgae; UNESCO: Paris, France, 2003; pp. 25-49.

133. Lawrence, J.F; Niedzwiadek, B.; Quantitative determination of paralytic shellfish poisoning toxins in shellfish by using prechromatographic oxidation and liquid chromatography with fluorescence detection. J. AOAC Int. 2001, 84, 1099-1108.

134. Kele, P.J.O.; Calhoun, T.L.; Gawley, R.E.; LEBlanc, R.M. Coumaryl crown ether based chemosensors: selective detection of saxitoxin in the presence of sodium and potassium ions. Tetrahedron Lett. 2002, 43, 4413-4416.

135. Gawley, R.E.; Pinet, S.; Cardona, C.M.; Datta, P.K.; Ren, T.; Guida, W.C.; Nydick, J.; Leblanc, R.M. Chemosensors for the marine toxin saxitoxin. J. Am. Chem. Soc. 2002, 124, 13448-13453.

136. Gawley, R.E.; Shanmugasundaram, M.; Thorne, J.B. Tarkka, R.M. Selective detection of saxitoxin over tetrodotoxin using acridinylmethyl crown ether chemosensor. Toxicon 2005, 45, 783-787.

137. Gawley, R.E.; Mao, H.; Haque, M.M.; Thorne, J.B.; Pharr, J.S. Visible fluorescence chemosensor for saxitoxin. J. Org. Chem. 2007, 72, 2187-2191.

138. Campbell, K.; Steart, L.D.; Doucette, G.J.; Fodey, T.L.; Haughey, S.A.; Vilariño, N.; Kawatsu, K.; Elliott, C.T. Assessment of specific binding proteins suitable for the detection of paralytic shellfish poisons using optical biosensor technology. Anal. Chem. 2007, 79, 5906-5914.

139. Fonfría, E.S.; Vilariño, N.; Campbell, K.; Elliott, C.T.; Haughey, S.A.; Ben-Gigirey, B.; Vieites, J.M.; Kawatsu, K.; Botana, L.M. Paralytic shellfish poisoning detection by surface plasmon resonance-based biosensor in shellfish matrixes. Anal. Chem. 2007, 79, 6303-6311.

140. Chu, F.S; Fan, T.S. Indirect enzyme-linked immunosorbent assay for saxitoxin in shellfish. $J$. Assoc. Anal. Chem. 1985, 68, 13-16.

141. Carlson, R.E.; Lever, M.L.; Lee, B.W.; Guire, P.E. Development of immunoassays for paralytic shellfish poisoning. A radioimmunoassay for saxitoxin. In Seafood toxins, SCS symposium Series 262; Ragelis, E.P., Ed.; American Chemical Society: Washington, DC, USA, 1984; pp. 181-192.

142. Doucette, G.J.; Logan, M.M.; Ramsdell, J.S.; Van Dolah, F.M. Development and preliminary validation of a microtiter plate-based receptor binding assay for paralytic shellfish poisoning toxins. Toxicon 1997, 35, 625-636. 
143. Ruberu, S.R.; Liu, Y.G.; Wong, C.T.; Perera, S.K.; Langlois, G.W.; Doucette, G.J.; Powell, C.L. Receptor binding assay for paralytic shellfish poisoning toxins: optimization and interlaboratory comparison. J. AOAC Int. 2003, 86, 737-745.

144. Vieytes, M.R.; Cabado, A.G.; Alfonso, A.; Louzao, M.C.; Botana, A.M.; Botana, L.M. Solid-phase radioreceptor assay for paralytic shellfish toxins. Anal. Biochem. 1993, 211, 87-93.

145. Vélez, P.; Suárez-Isla, B.A.; Sierralta, J.; Fonseca, M.; Loyola, H.; Johns, D.C.; Tomaselli, G.F.; Marbán, E. Electrophysiological assay to quantify saxitoxins in contaminated shellfish. Biophys. J. 1999, 76, A82.

146. Louzao, M.C.; Rodriguez Vieytes, M.; Garcia Cabado, A.; Vieites Baptista De Sousa, J.M.; Botana, L.M. A fluorimetric microplate assay for detection and quantitation of toxins causing paralytic shellfish poisoning. Chem. Res. Toxicol. 2003, 16, 433-438.

147. Louzao, M.C.; Vieytes, M.R.; Baptista de Sousa, J.M.; Leira, F.; Botana, L.M. A fluorimetric method based on changes in membrane potential for screening paralytic shellfish toxins in mussels. Anal. Biochem. 2001, 289, 246-250.

148. Thibault, P.; Pleasance, S.; Laycock, M.V. Analysis of paralytic shellfish poisons by capillary electrophoresis. J. Chromatogr. 1991, 542, 483-501.

149. Jeffery, B.; Barlow, T.; Moizer, K.; Paul, S.; Boyle, C. Amnesic shellfish poison. Food Chem. Toxicol. 2004, 42, 545-557.

150. Quilliam, M.A. Phycotoxins. J. AOAC Int. 1999, 82, 773-781.

151. Amzil, Z.; Fresnel, J.; Le Gal, D.; Billard, C. Domoic acid accumulation in French shellfish in relation to toxic species of Pseudo-nitzschia multiseries and P. pseudodelicatissima. Toxicon 2001, 39, 1245-1251.

152. Vale, P. Chemistry of dhiarrhetic shellfish poisoning toxins. In Phycotoxins: chemistry and biochemistry; Botana, L.M., Ed.; Blackwell Publishing: Ames, IA, USA, 2007; pp. 211-221.

153. Bates, S.S.; Bird, C.J.; deFreitas, A.S.W.; Foxall, R.; Gilgan, M.; Hanic, L.A.; Johnson, G.R.; McCulloch, A.W.; Odense, P.; Pocklington, R.; Quilliam, M.A.; Sim, P.G.; Smith, J.C.; SubbaRao, D.V.; Todd, E.C.D.; Walter, J.A.; Wright, J.L.C. Pennate diatom Nitzschia pungens as the primary source of domoic acid, a toxin in shellfish from eastern Prince Edward Island, Canada. Can. J. Fisheries Aquat. Sci. 1991, 46, 1203-1215.

154. Nijjar, M.S; Nijjar, S.S. Ecobiology, clinical symptoms, and mode of action of domoic acid, an amnesic shellfish toxin. In Seafood and freshwater toxins: pharmacology, physiology and detection; Botana, L.M., Ed.; Marcel Dekker: New York, NY, USA, 2000; pp. 325-358.

155. EC. Commision Regulation (EC) No 1244/2007 of 24 October 2007 amending Regulation (EC) No 2074/2005 as regards implementing measures for certain products of animal origin intended for human consumption and laying down specific rules on official controls for the inspection of meat. Offic. J. L Counc. Eur. Communities 2007, 281, 12-18.

156. Yu, Q.; Chen, S.; Taylor, A.D.; Homola, J.; Hock, B.; Jiang, S. Detection of low-molecular-weight domoic acid using surface plasmon resonance sensor. Sens. Actuat. B. 2005, 107, 193-201.

157. Kania, M; Hock, B. Development of monoclonal antibodies to domoic acid for the detection of domoic acid in blue mussel (Mytilus edulis) tissue by ELISA. Anal. Lett. 2002, 35, 855-868. 
158. Traynor, I.M.; Plumpton, L.; Fodey, T.L.; Higgins, C.; Elliott, C.T. Immunobiosensor detection of domoic acid as a screening test in bivalve molluscs: comparison with liquid chromatographybased analysis. J. AOAC Int. 2006, 89, 868-872.

159. Lotierzo, M.; Henry, O.Y.; Piletsky, S.; Tothill, I.; Cullen, D.; Kania, M.; Hock, B.; Turner, A.P. Surface plasmon resonance sensor for domoic acid based on grafted imprinted polymer. Biosens. Bioelectron. 2004, 20, 145-152.

160. Micheli, L.; Radoi, A.; Guarrina, R.; Massaud, R.; Bala, C.; Moscone, D.; Palleschi, G. Disposable immunosensor for the determination of domoic acid in shellfish. Biosens. Bioelectron. 2004, 20, 190-196.

161. Quilliam, M.A.; Thomson, B.A.; Scott, G.J.; Siu, K.W. Ion-spray mass spectrometry of marine neurotoxins. Rapid Commun. Mass. Spectrom. 1989, 3, 145-150.

162. Quilliam, M.A.; Thomas, K.; Wright, J.L. Analysis of domoic acid in shellfish by thin-layer chromatography. Nat. Toxins. 1998, 6, 147-152.

163. Zhao, J.Y.; Thibault, P.; Quilliam, M.A. Analysis of domoic acid and isomers in seafood by capillary electrophoresis. Electrophoresis 1997, 18, 268-276.

164. Poli, M.A.; Lewis, R.J.; Dickey, R.W.; Musser, S.M.; Buckner, C.A.; Carpenter, L.G. Identification of Caribbean ciguatoxins as the cause of an outbreak of fish poisoning among U.S. soldiers in Haiti. Toxicon 1997, 35, 733-741.

165. Lombet, A.; Bidard, J.N.; Lazdunski, M. Ciguatoxin and brevetoxins share a common receptor site on the neuronal voltage-dependent Na+ channel. FEBS Lett. 1987, 219, 355-359.

166. Van Egmond, H.P.; Speyers, G.J.A.; Van den Top, H.J. Current situation on worldwide regulations for marine phycotoxins. J. Nat. Toxins 1992, 1, 67-85.

167. Hokama, Y.; Banner, A.H.; Boylan, D.B.; A radioimmunoassay for the detection of ciguatoxin. Toxicon 1977, 15, 317-325.

168. Campora, C.E.; Hokama, Y.; Ebesu, J.S. Comparative analysis of purified Pacific and Caribbean ciguatoxin congeners and related marine toxins using a modified ELISA technique. J. Clin. Lab. Anal. 2006, 20(3),121-5.

169. Campora, C.E.; Hokama, Y.; Yabusaki, K.; Isobe, M.; Development of an enzyme-linked immunosorbent assay for the detection of ciguatoxin in fish tissue using chicken immunoglobulin Y. J. Clin. Lab. Anal. 2008, 22, 239-245.

170. Hokama, Y.; Abad, M.A.; Kimura, L.H. A rapid enzyme-immunoassay for the detection of ciguatoxin in contaminated fish tissues. Toxicon 1983, 21, 817-824.

171. Oguri, H.; Hirama, M.; Tsumuraya, T.; Fujii, I.; Maruyama, M.; Uehara, H.; Nagumo, Y. Synthesis-based approach toward direct sandwich immunoassay for ciguatoxin CTX3C. J. Am. Chem. Soc. 2003, 125, 7608-7612.

172. Hokama, Y. A rapid, simplified enzyme immunoassay stick test for the detection of ciguatoxin and related polyethers from fish tissues. Toxicon 1985, 23, 939-946.

173. Park, D.L. Detection of ciguatera and diarrheic shellfish toxins in finfish and shellfish with Ciguatec kit. J. AOAC Int. 1995, 78, 535-537.

174. Lewis, R.J; Jones, A. Characterization of ciguatoxins and ciguatoxin congeners present in ciguateric fish by gradient reverse-phase high-performance liquid chromatography/mass spectrometry. Toxicon 1997, 35, 159-168. 
175. Wiles, J.S.; Vick, J.A.; Christensen, M.K. Toxicological evaluation of palytoxin in several animal species. Toxicon 1974, 12, 427-433.

176. Katikou, P. Palytoxin and analogues: ecobiology and origin, chemistry, metabolism, and chemical analysis. In Seafood and freshwater toxins: pharmacology, physiology and detection, 2nd ed.; Botana, L.M., Ed.; CRC Press: Boca Raton, FL, USA, 2008; pp. 631-663.

177. Frolova, G.M.; Kuznetsova, T.A.; Mikhailov, V.V.; Elyakov, G.B. An enzyme linked immunosorbent assay for detecting palytoxin-producing bacteria. Russ. J. Bioorg. Chem. 2000, 26, 285-289.

178. Uemura, D.; Hirata, Y.; Iwashita, T.; Naoki, H. Studies on palytoxin. Tetrahedron 1985, 41, 1007-1017.

179. Beress, L.; Zwick, J.; Kolkenbrock, H.J.; Kaul, P.N.; Wassermann, O. A method for the isolation of the caribbean palytoxin (C-PTX) from the coelenterate (zooanthid) Palythoa caribaeorum. Toxicon 1983, 21, 285-290.

180. Ciminiello, P.; Dell'Aversano, C.; Fattorusso, E.; Forino, M.; Magno, G.S.; Tartaglione, L.; Grillo, C.; Melchiorre, N. The Genoa 2005 outbreak. Determination of putative palytoxin in Mediterranean Ostreopsis ovata by a new liquid chromatography tandem mass spectrometry method. Anal. Chem. 2006, 78, 6153-6159.

181. Kimura, S.; Hashimoto, Y.; Yamazato, K. Toxicity of the zoanthid Palythoa tuberculosa. Toxicon 1972, 10, 611-617.

182. Moore, R.E; Scheuer, P.J. Palytoxin: a new marine toxin from a coelenterate. Science 1971, 172, 495-498.

183. Artigas, P; Gadsby, D.C. Na+/K+-pump ligands modulate gating of palytoxin-induced ion channels. Proc. Natl. Acad. Sci. USA 2003, 100, 501-505.

184. Fusetani, N.; Sato, S.; Hashimoto, K. Occurrence of a water soluble toxin in a parrotfish (Ypsiscarus ovifrons) which is probably responsible for parrotfish liver poisoning. Toxicon 1985, 23, 105-112.

185. Kodama, A.M.; Hokama, Y.; Yasumoto, T.; Fukui, M.; Manea, S.J.; Sutherland, N. Clinical and laboratory findings implicating palytoxin as cause of ciguatera poisoning due to Decapterus macrosoma (mackerel). Toxicon 1989, 27, 1051-1053.

186. Gallitelli, M.; Ungaro, N.; Addante, L.M.; Procacci, V.; Silveri, N.G.; Sabba, C. Respiratory illness as a reaction to tropical algal blooms occurring in a temperate climate. JAMA 2005, 293, 2599-2600.

187. Habermann, E. Palytoxin acts through $\mathrm{Na}+, \mathrm{K}+-\mathrm{ATPase}$. Toxicon 1989, 27, 1171-1187.

188. Hilgemann, D.W. From a pump to a pore: how palytoxin opens the gates. Proc. Natl. Acad. Sci. USA 2003, 100, 386-388.

189. Reyes, N; Gadsby, D.C. Ion permeation through the $\mathrm{Na}+, \mathrm{K}+-\mathrm{ATPase}$. Nature 2006, 443, 470-474.

190. Espina, B.; Cagide, E.; Louzao, M.C.; Fernandez, M.M.; Vieytes, M.R.; Katikou, P.; Villar, A.; Jaen, D.; Maman, L.; Botana, L.M. Specific and dynamic detection of palytoxins by in vitro microplate assay with human neuroblastoma cells. Biosci. Rep. 2009, 29, 13-23. 
191. Bignami, G.S.; Raybould, T.J.; Sachinvala, N.D.; Grothaus, P.G.; Simpson, S.B.; Lazo, C.B.; Byrnes, J.B.; Moore, R.E.; Vann, D.C. Monoclonal antibody-based enzyme-linked immunoassays for the measurement of palytoxin in biological samples. Toxicon 1992, 30, 687-700.

192. Lau, C.O.; Tan, C.H.; Khoo, H.E.; Yuen, R.; Lewis, R.J.; Corpuz, G.P.; Bignami, G.S. Lophozozymus pictor toxin: a fluorescent structural isomer of palytoxin. Toxicon 1995, 33, 1373-1377.

193. Bignami, G.S. A rapid and sensitive hemolysis neutralization assay for palytoxin. Toxicon 1993, 31, 817-820.

194. Kanchanapongkul, J; Krittayapoositpot, P. An epidemic of tetrodotoxin poisoning following ingestion of the horseshoe crab Carcinoscorpius rotundicauda. Southeast Asian J Trop. Med. Publ. Health 1995, 26, 364-367.

195. Lange, W.R. Puffer fish poisoning. Am. Fam. Physician 1990, 42, 1029-1033.

196. Yang, C.C.; Liao, S.C.; Deng, J.F. Tetrodotoxin poisoning in Taiwan: an analysis of poison center data. Vet. Hum. Toxicol. 1996, 38, 282-286.

197. Bradley, S.G; Klika, L.J. A fatal poisoning from the Oregon rough-skinned newt (Taricha granulosa). JAMA 1981, 246, 247.

198. Sims, J.K; Ostman, D.C.; Pufferfish poisoning: emergency diagnosis and management of mild human tetrodotoxication. Ann. Emerg. Med. 1986, 15, 1094-1098.

199. Adams, M.E; Olivera, B.M. Neurotoxins: overview of an emerging research technology. Trends Neurosci. 1994, 17, 151-155.

200. EC. Council Directive 91/493/EEC of 22 July 1991 laying down the health conditions for the production and the placing on the market of fishery products. Offic. J. L Counc. Eur. Communities 1991, 332, 15-34.

201. Neagu, D.; Micheli, L.; Palleschi, G. Study of a toxin-alkaline phosphatase conjugate for the development of an immunosensor for tetrodotoxin determination. Anal. BioAnal. Chem. 2006, 385, 1068-1074.

202. Cheun, B.; Endo, H.; Hayashi, T.; Nagashima, Y.; Watanabe, E. Development of an ultra high sensitive tissue biosensor for determination of swellfish poisoning, tetrodotoxin. Biosens. Bioelectron. 1996, 11, 1185-1191.

203. Cheun, B.S.; Loughran, M.; Hayashi, T.; Nagashima, Y.; Watanabe, E. Use of a channel biosensor for the assay of paralytic shellfish toxins. Toxicon 1998, 36, 1371-1381.

204. Cheun, B.S.; Takagi, S.; Hayashi, T.; Nagashima, Y.; Watanabe, E. Determination of Na channel blockers in paralytic shellfish toxins and pufferfish toxins with a tissue biosensor. J. Nat. Toxins. 1998, 7, 109-120.

205. Pancrazio, J.J.; Gray, S.A.; Shubin, Y.S.; Kulagina, N.; Cuttino, D.S.; Shaffer, K.M.; Eisemann, K.; Curran, A.; Zim, B.; Gross, G.W.; O'Shaughnessy, T.J. A portable microelectrode array recording system incorporating cultured neuronal networks for neurotoxin detection. Biosens. Bioelectron. 2003, 18, 1339-1347.

206. Pancrazio, J.J.; Kulagina, N.V.; Shaffer, K.M.; Gray, S.A.; O’Shaughnessy, T.J. Sensitivity of the neuronal network biosensor to environmental threats. J. Toxicol. Environ. Health A 2004, 67, 809-818. 
207. Kawatsu, K.; Hamano, Y.; Yoda, T.; Terano, Y.; Shibata, T. Rapid and highly sensitive enzyme immunoassay for quantitative determination of tetrodotoxin. Jpn. J. Med. Sci. Biol. 1997, 50, 133-150.

208. Rivera, V.R.; Poli, M.A.; Bignami, G.S. Prophylaxis and treatment with a monoclonal antibody of tetrodotoxin poisoning in mice. Toxicon 1995, 33, 1231-1237.

209. Gallacher, S; Birkbeck, T.H. A tissue culture assay for direct detection of sodium channel blocking toxins in bacterial culture supernates. FEMS Microbiol. Lett. 1992, 71, 101-107.

210. Zhang, Y.L.; Dunlop, J.; Dalziel, J.E. Recombinant human voltage-gated skeletal muscle sodium channels are pharmacologically functional in planar lipid bilayers. Biosens. Bioelectron. 2007, 22, 1006-1012.

(C) 2009 by the authors; licensee Molecular Diversity Preservation International, Basel, Switzerland. This article is an open-access article distributed under the terms and conditions of the Creative Commons Attribution license (http://creativecommons.org/licenses/by/3.0/). 